\title{
Matematiikan parhaiden osaajien siirtyminen toiselle asteelle: koulutusvalinnat ja matematiikan osaamisen kehittyminen
}

\author{
Laura Niemi ${ }^{1}$, Jari Metsämuuronen², Markku S. Hannula ${ }^{1} \&$ Anu Laine ${ }^{1}$ \\ ${ }^{1}$ Helsingin yliopisto \\ ${ }^{2}$ Kansallinen koulutuksen arviointikeskus
}

Tutkimus on osa pitkittäistutkimusta, jossa samaan ikäluokkaan kuuluvia oppilaita seurattiin perusopetuksen kolmannelta vuosiluokalta toisen asteen koulutuksen loppuun neljällä eri mittauskerralla. Tutkimuksessa käytetään Opetushallituksen ja Kansallisen koulutuksen arviointikeskuksen vuosien 2005-2015 aikana keräämää kansallisesti edustavaa tutkimusaineistoa. Tutkimusaineisto käsittää kaikkiaan 3896 oppilasta. Tutkimuksessa keskitytään tarkastelemaan matematiikan parhaita osaajia, joita on yhteensä $292(7,5 \%)$. Poikien osuus on $64,0 \%(n=187)$ ja tyttöjen $36,0 \%(n=105)$. Osaaminen määritetään yhdeksännen vuosiluokan kokeessa menestymisen perusteella. Kansallisten matematiikan kokeiden lisäksi oppilaat ovat vastanneet erilaisiin kyselyihin, joissa heiltä on kerätty tietoa yksilöön, kouluun ja kotitaustaan liittyvistä tekijöistä. Tutkimuksessa selvitetään näiden tekijöiden yhteyttä toisen asteen koulutusvalintaan ja osaamisen kehittymiseen toisen asteen opintojen aikana. Tulosten analysoinnissa käytettiin päätöspuuanalyysia (DTA) ja regressioanalyysia. Tutkimuksessa havaittiin, että suurin osa $(60,0 \%)$ yhdeksännen vuosiluokan parhaista osaajista oli parhaita osaajia myös toisen asteen päättyessä ja muiden osaaminen laski hyvien tai keskitason osaajien tasolle. Yksilöön liittyvät tekijät selittävät parhaiten matematiikassa menestymistä myös toisella asteella. Myönteiset asenteet matematiikkaa kohtaan ja vahva matematiikan osaamisen pohja perusopetuksessa luovat edellytyksiä menestyä matematiikassa erinomaisesti toisella asteella. Matematiikan parhaiden osaajien osaamisen taso heikkenee todennäköisemmin, jos oppilas ei mene lukioon tai ei suorita lukiossa vähintään 11 matematiikan kurssia. Yhdeksännen vuosiluokan parhaista osaajista lukioon hakeutuivat todennäköisemmin ne, jotka menestyivät arvosanatiedon perusteella erinomaisesti äidinkielessä.

Avainsanat: matematiikan parhaat osaajat, pitkittäistutkimus, kansallinen arviointi, matematiikan oppimistulokset, toinen aste

\author{
ARTIKKELIN TIEDOT \\ LUMAT General Issue \\ Vol 9 No 1 (2021), 457-494 \\ Lähetetty 21. helmikuuta 2021 \\ Hyväksytty 31. toukokuuta 2021 \\ Julkaistu 9. kesäkuuta 2021 \\ Sivuja: 38 \\ Lähteitä: 98 \\ Yhteydenotot: \\ laura.niemi@helsinki.fi \\ https://doi.org/10.31129/ \\ LUMAT.9.1.1511
}

\section{Johdanto}

Useimmat matematiikassa parhaiten menestyneistä oppilaista eriytyvät muista oppilaista jo perusopetuksen varhaisessa vaiheessa. Niemen, Metsämuurosen, Hannulan ja Laineen (2020) mukaan valtaosa yhdeksännen vuosiluokan parhaista osaajista erottui muista jo kolmannen vuosiluokan alussa, ja erot osaamisessa näkyivät selkeästi kuudennella vuosiluokalla. Kansainvälisesti arvioituna erinomaisten matematiikan osaajien osuus suomalaisoppilaista on kuitenkin laskenut huomattavasti. Tämä näkyy muun muassa PISA-tuloksissa vuosien 2003 ja 
2015 välisenä aikana (Vettenranta ym., 2016, s. 40). Osaamisen lasku on huolestuttavaa, koska vahvoja matematiikan osaajia tarvitaan eri aloilla. Ongelmana onkin, miten erinomaiset matematiikan osaajat voidaan tunnistaa ja miten heidän osaamistaan voidaan tukea peruskoulun ja toisen asteen opintojen aikana.

Tämä tutkimus on osa pitkittäistutkimusta, jossa samaan ikäluokkaan kuuluvia oppilaita seurattiin vuosina 2005-2015 perusopetuksen kolmannelta vuosiluokalta toisen asteen koulutuksen loppuun. Tutkimusaineisto on Opetushallituksen ja Kansallisen koulutuksen arviointikeskuksen (Karvi) keräämä. Tarkentavassa aineiston analyysissa selvitettiin, miten matematiikassa parhaiten menestyvät yhdeksäsluokkalaiset erottuvat muista oppilaista ja miten heidän osaamisensa on kehittynyt perusopetuksen aikana. Tutkimustulokset osoittivat muun muassa, että oppilaan aikaisempi osaaminen, käsitys omasta osaamisesta ja vanhempien koulutustaso olivat selkeitä parempaa osaamista selittäviä tekijöitä (Niemi ym., 2020).

Useat tutkimukset ovat osoittaneet, että omiin kykyihinsä luottavat ja motivoituneet oppilaat menestyvät matematiikan opinnoissa parhaiten. Esimerkiksi Murayama, Pekrun, Lichtenfeld ja vom Hofe (2012) tutkivat, miten motivaatio, opiskelutyyli ja älykkyys selittävät matematiikassa edistymistä Saksassa viidenneltä luokalta kymmenennelle. Tutkimuksessa seurattiin 3500 koululaisen matematiikan osaamisen kehitystä viiden vuoden aikana. Tulokset osoittivat, että motivaatio ja opiskelutyyli ovat älykkyyttä tärkeämpiä tekijöitä matematiikan osaamisen edistymisessä; älykkyydellä on merkitystä vain opintojen alussa.

Tämän tutkimuksen tarkoituksena on selvittää, mitä muutoksia matematiikassa parhaiten menestyneiden yhdeksäsluokkalaisten osaamisessa tapahtuu toisen asteen opintojen aikana ja kuinka paljon yksilöön liittyvät tekijät ja toisaalta koulu- ja kotiympäristöön liittyvät tekijät ovat yhteydessä matematiikan osaamiseen ja siinä tapahtuviin muutoksiin. Tutkimus tarjoaa koulutuspoliittisesti merkittävää tietoa matematiikan parhaista osaajista ja siitä, miten heidän osaamisensa voidaan tunnistaa opintojen aikana. Tirri ja Kuusisto (2013) ovat esittäneet, että erinomaisten ja lahjakkaiden oppilaiden tunnistaminen ja tukeminen on yksi suomalaisen koulujärjestelmän haasteista. Koulujärjestelmässämme on ollut periaatteena pitää huolta heikoista oppilaista ja tukea niitä, joilla on oppimisvaikeuksia (Tirri \& Kuusisto, 2013). Peruskoulu-uudistuksen lähtökohtana 1970-luvulla oli edistää koulutuksen tasa-arvoa ja tasoittaa oppilaiden koulutusmahdollisuuksia. Tällaisen koulutuksellisen tasa-arvon nähdään olevan myös yksi tekijöistä Suomen PISA- 
menestyksen taustalla (Niemi, 2012). Opetussuunnitelman perusteiden mukaan kaiken opetuksen pedagogisena lähtökohtana tulisi olla eriyttäminen, joka perustuu oppilaiden tarpeille ja mahdollisuuksille muun muassa edetä yksilöllisesti (Opetushallitus, 2014, s. 5). Tällainen opetuksen eriyttäminen koskee kuitenkin useimmiten vain oppilaita, joilla on oppimisvaikeuksia, ja lahjakkaiden oppilaiden tukeminen riippuu yksittäisestä opettajasta (Laine, 2016, s. 13). Tutkimuksessa onkin tarkoitus selvittää, millainen merkitys kouluun liittyvillä tekijöillä on matematiikan parhaiden osaajien osaamisen kehittymisessä verrattuna oppilaan yksilöllisiin tekijöihin.

\section{Matematiikan parhaat osaajat}

Matematiikan parhaiden osaajien määrittely ei ole yksiselitteistä. Tässä tutkimuksessa tarkastellaan oppilaita, jotka ovat menestyneet erinomaisesti koulumatematiikkaa mittaavissa tehtävissä. Matematiikassa erinomaisesti menestyneitä oppilaita käsittelevien tutkimusten voidaan nähdä tarkastelevan menestymistä seuraavista näkökulmista. Oppilas saa huipputuloksia, koska hän on poikkeuksellisen lahjakas eikä hänen tarvitse tehdä töitä osaamisensa eteen vaan hän omaksuu asioita vain pienellä ohjauksella (mm. Sternberg \& Davidson, 2005). Vaihtoehtoisesti oppilaan voidaan sanoa olevan matemaattisesti lupaava, joka omaksuu helposti matemaattisia asioita (Sheffield ym., 1999) tai, että oppilas saa erinomaisia tuloksia, kun tekee paljon töitä oppimisensa eteen (mm. Boaler, 2015).

Matemaattinen lahjakkuus tai lahjakkuus ylipäätänsä on vaikeasti määriteltävä käsite eikä sen määrittämiseksi voida käyttää yhtä ainoaa erityistä kriteeriä (mm. Sternberg, 1993; Gagné, 1995; 2000; Wellisch \& Brown, 2012). Muun muassa Sternbergin ja Davidsonin (2005) mukaan matemaattisen lahjakkuuden ajatellaan olevan synnynnäinen persoonan ominaisuus ja matemaattiset taidot ovat seurausta matemaattisesta lahjakkuudesta. Krutetskii (1976) määrittelee matemaattisen lahjakkuuden yksilölliseksi kokoelmaksi matemaattisia taitoja, jotka mahdollistavat menestymisen matematiikassa. Kun yksilöllä on tarvittava määrä matemaattisia kykyjä ja hänen persoonallisuutensa piirteet sekä myös jotkin geneettiset ominaisuudet ovat sopivat, voidaan puhua matemaattisesta lahjakkuudesta. Matemaattinen lahjakkuus voi ilmetä taitona suorittaa menestyksekkäästi kokeita ja testejä, hankkia tietoa, mutta myös kyvykkyyttä kehittää ja tuottaa uutta (Singer ym., 2016). Matemaattisesti lahjakas ei kuitenkaan aina välttämättä saavuta huipputuloksia matematiikassa eikä matematiikassa hyvin menestyvä oppilas ole 
välttämättä matemaattisesti lahjakas (mm. Brandl \& Barthel, 2012; Szabo, 2015). Oppilaan sisäisellä motivaatiolla on keskeinen merkitys matematiikan osaamisessa ja sen kehittymisessä, ja opettajan rooli kiinnostuksen herättäjänä ja ylläpitäjänä on tärkeä (Krutetskii, 1976).

Lahjakkuus ylipäätänsä nähdäänkin nykyään usein mallina, jossa kognitioon, motivaatioon ja ympäristöön liittyvät tekijät ovat toisiinsa yhteydessä ja johtavat lahjakkaaseen käyttäytymiseen (Vlahovic-Stetic ym., 1999). Muun muassa Renzulli (1985; 2002) näkee lahjakkuuden koostuvan kolmesta elementistä, jotka ovat keskitason ylittävä kyvykkyys (above-average ability), opiskelumotivaatio (task commitment) ja luovuus (creativity). Renzullin mallissa keskitason ylittävä kyvykkyys viittaa henkilön kognitiivisiin kykyihin, opiskelumotivaatio henkilön kiinnostukseen tai sitoutumiseen aiheeseen ja korkea luovuus liittyy ajatuksen omaperäisyyteen. Henkilö on lahjakas, kun hänellä on kaikki kolme ominaisuutta. Mönks (1992) sisällyttää jaotteluun myös koulun, perheen ja opiskelutoverit. Mönks ja Mason (2000) kuvaavat, miten yksilölliset tekijät (stressitekijät, sosiaaliset tekijät ja motivaatiotekijät) ja ympäristötekijät (kouluun, ikätasoon ja vanhempiin liittyvät tekijät) vaikuttavat lahjakkaan käyttäytymiseen.

Matemaattisen lahjakkuuden rinnalle on esitetty käsitettä matemaattinen lupaavuus (Sheffield ym., 1999). Käsitteen kuvauksen mukaan matemaattisia kykyjä voidaan kehittää eikä matemaattinen osaaminen ole puhtaasti synnynnäinen ominaisuus, kuten lahjakkuudesta ajatellaan. Tämän mukaan suuremmalla määrällä yksilöitä on mahdollisuus yltää erinomaisiin matematiikan tuloksiin. Matemaattinen lupaavuus määritellään koostuvan neljästä osatekijästä, jotka ovat toisiinsa vastavuoroisessa yhteydessä. Oppilas voi saavuttaa korkean matemaattisen suorituskyvyn, kun hänen potentiaalinsa pääsee toteutumaan koko laajuudessaan. Matemaattinen lupaavuus koostuu Sheffieldin ja kanssakirjoittajien (1999) mukaan kyvykkyydestä (ability), motivaatiosta (motivation), uskomuksesta (belief) ja kokemuksesta (experience) tai mahdollisuudesta (opportunity). Osatekijät ovat toisiinsa yhteydessä ja kaikkia niitä on kehitettävä, jotta oppilaan potentiaali saadaan maksimoitua. Lupaavuuden käsite korostaa olosuhteiden vaikutusta osaamisen kehittymiseen. Dweckin (2006) mukaan oppilaat, jotka uskovat matemaattisen osaamisensa olevan täysin synnynnäistä (fixed mindset), pärjäävät heikommin kuin ne keskitason oppilaat, jotka tiedostavat, että voivat kehittää osaamistaan (growth mindset). Boalerin (2015) mukaan jokaisella oppilaalla on mahdollisuus menestyä matematiikassa tekemällä töitä oppimisensa eteen. 
Myös Leikin (2014) näkee, että erinomaiset taidot matematiikassa ovat kehitettävissä. Älyllisten kykyjen kehittämiseen vaikuttavat kuitenkin yksilön persoonalliset piirteet, kuten motivaatio, stressitekijät, kiinnostuksen kohteet, minäpystyvyys (self-efficacy) ja itseluottamus (self-belief) (Bandura \& Schunk, 1981; Zimmerman, 2000; Pajares, 2003) Myös useat matemaattiseen lahjakkuuteen liittyvät pitkittäistutkimukset osoittavat, että personallisuusominaisuuksilla, kuten motivaatiolla ja tunnetiloilla on tärkeä rooli poikkeuksellisen kyvyn kehittämisessä (Lubinski \& Benbow, 2006).

Seuraavaksi tarkastellaan, miten eri tekijät ovat aikaisempien tutkimustulosten mukaan yhteydessä matematiikan osaamiseen ja sen kehittymiseen.

\section{Matematiikan osaamiseen yhteydesså olevia tekijöitå}

Matematiikan osaamiseen yhteydessä olevia tekijöitä voidaan tarkastella monesta eri näkökulmasta. Metsämuuronen (2009) on luonut mallin, jossa oppimiseen, oppimistuloksiin ja oppimistulosten muutokseen vaikuttavia tekijöitä tarkastellaan kahdeksasta eri näkökulmasta: opiskelijaan liittyvät yksilölliset tekijät, vertaisryhmään liittyvät tekijät, kotiin ja perheeseen liittyvät tekijät, opettajaan ja opettamiseen liittyvät tekijät, koulun johtamiseen liittyvät tekijät, koulun fyysisiin olosuhteisiin liittyvät tekijät, taloustekijät ja demografiset tekijät. Näistä taustatekijöistä tässä tutkimuksessa tarkastellaan kolmea keskeistä näkökulmaa: yksilöön liittyvät tekijät, kouluun liittyvät tekijät ja kotitaustaan liittyvät tekijät. Yksilöön liittyviin tekijöihin luokittuvat esimerkiksi sukupuoli, aikaisempi osaaminen ja asenteet. Kouluun liittyviin tekijöitä ovat esimerkiksi opetukselliset tekijät ja vertaisryhmä koulussa. Kotitaustaan liittyviä tekijöitä ovat esimerkiksi oppilaan kielitausta, sosioekonominen tausta ja kodin antama tuki matematiikan opiskeluun.

\subsection{Yksilöön liittyvät tekijät}

Oppilaan yksilöllisistä tekijöistä osaamiseen ja sen kehittymiseen vaikuttavat kognitiivisten tekijöiden kuten aikaisemman osaamisen lisäksi muun muassa sukupuoli ja matematiikkaan liittyvät asenteet. Tässä luvussa keskitytään tarkastelemaan sukupuolta ja asenteita, jotka ovat aikaisempien tutkimustulosten valossa keskeisiä matematiikan osaamiseen yhteydessä olevia tekijöitä.

Sukupuolten välisistä eroista osaamisessa raportoidaan jatkuvasti sekä kansallisissa että kansainvälisissä oppimistulosarvioinneissa. Kansallisten 
oppimistulosarviointia koskevien lähtötasomittaustulosten mukaan matematiikan osaamisessa on havaittu olevan sukupuolten välillä eroa jo koulun aloitusvaiheessa (Ukkola \& Metsämuuronen, 2019). Kansainvälisesti tarkasteltuna Suomessa tytöt ja pojat osaavat matematiikkaa keskimäärin yhtä hyvin, mutta erot näkyvät kaikkein korkeimmilla taitotasoilla, joissa pojat ovat yliedustettuja. Esimerkiksi PISA 2018 tulosten (Leino ym., 2019) mukaan suurin osa suomalaistytöistä ja -pojista menestyy koulussa yhtä hyvin, mutta poikien osaamisessa on enemmän vaihtelua.

Pojat ovat yleisesti tyttöjä parempia matematiikassa ja tytöt lukemisessa ja poikien osaamisen vaihtelu on tyttöjen osaamisen vaihtelua suurempaa maailmanlaajuisesti ja koulutuksellisista ratkaisuista riippumatta (mm. Machin \& Pekkarinen, 2008). Meta-analyysin (O’Dea ym., 2018) mukaan poikien suurempi vaihtelu on pysynyt samanlaisena viimeisten 80 vuoden aikana ja se näkyy erityisesti matemaattisluonnontieteellisissä aineissa. Tällaiselle vaihteluhypoteesille (variability hypothesis) on ehdotettu löytyvän osaselitys perinnöllisyydestä (Johnson ym., 2008).

Yksilön matematiikkaan liittyvien asenteiden yhteyttä osaamiseen on tutkittu paljon sekä kansainvälisesti että kansallisesti ja osaamisen ja asenteiden on havaittu välillä olevan selkeä yhteys (Ma \& Kishor, 1997). Yhteyttä ei ole kuitenkaan kovin laajasti ja tarkasti analysoitu, ja asenteiden ja osaamisen välinen syy-seuraussuhde on jäänyt epäselväksi (esim. Leder, 2006).

Kansallisten oppimistulosarviointien (mm. Tuohilampi \& Hannula, 2013; Metsämuuronen, 2017) mukaan asenteilla ja matematiikan osaamisella on vahva positiivinen yhteys. Sen voimakkuus kuitenkin vaihtelee vuosiluokkakohtaisesti vahvistuen ikävuosien myötä (Tuohilampi \& Hannula, 2013). Pääsääntöisesti oppilaiden asenteet koulunkäyntiä ja oppimista kohtaan ovat ensimmäisinä kouluvuosina positiivisia. Oppilailla on silloin yleisesti myönteiset asenteet niin koulunkäyntiä kuin myös eri oppiaineita kohtaan (Harter, 1999; Metsämuuronen ym., 2012; Tuohilampi ym., 2013).

Tuohilammen ja Hannulan (2013) mukaan asenteiden muutos näkyy pitkittäisaineistossa kolmannelta luokalta yhdeksännelle aluksi vain matematiikasta pitämisessä, joka heikentyy olennaisesti kuudennella luokalla. Minäpystyvyys ja hyödyllisyyden kokeminen laskevat selvästi yläkoulun aikana. Tuohilammen ja Hannulan (2013, s. 236) mukaan tällaisella asenteiden muutoksella kielteisemmiksi voi olla seurauksia opiskeluvalintoihin ja tuleviin opintoihin sekä elämässä menestymiseen. 
Minäpystyvyyden ja osaamisen välisen suhteen kausaliteetista on tehty erilaisia päätelmiä. Positiivisen minäpystyvyyden on havaittu selittävän hyviä oppimistuloksia ja vastavuoroisesti hyvät oppimistulokset selittävät luottamusta omaan osaamiseen. Muun muassa Williamsin ja Williamsin (2010) PISA-aineistoon pohjautuvan kansainvälisen vertailuanalyysin mukaan matemaattisen minäpystyvyyden vaikutus suoriutumiseen on Suomessa suhteellisen pieni muihin maihin verrattuna, mutta tilastollisesti merkitsevä, ja matematiikan osaamisen vaikutus minäpystyvyyteen yksi suurimmista. Banduran (1986) sekä Pajaresin ja Millerin (1994) mukaan minäpystyvyyden tunne selittää tulevaa osaamistasoa muita matematiikkaan liittyviä asenteita paremmin, kun minäpystyvyys ohjaa yksilön käyttäytymistä ja valintoja. Myös uudemmissa tutkimuksissa vahvan käsityksen omasta osaamisesta on todettu ennustavan parempaa koulumenestystä (mm. Bryan ym., 2011; Jiang ym., 2014; Suárez-Álvarez ym., 2014). Myös PISA2012-tutkimuksessa matematiikan minäkäsityksen ja suoritusluottamuksen on havaittu selittävän vahvimmin matematiikan osaamista kansallisella tasolla (Kupari \& Nissinen, 2015).

Hannulan, Bofahin, Tuohilammen ja Metsämuurosen (2014) tekemän pitkittäisanalyysin mukaan osaaminen vaikuttaa minäpystyvyyden kehittymiseen luokilla 3-6, ja luokka-asteilla 6-9 osaaminen ja minäpystyvyys ovat vastavuoroisessa suhteessa. Hannulan ja Laakson (2011) mukaan osaamisen ja asenteiden välinen yhteys voimistuu iän karttuessa, kun käsitykset muuttuvat realistisimmiksi. Matematiikan parhaisiin osaajiin keskittyvän pitkittäisanalyysin mukaan (Niemi ym., 2020) vahva minäpystyvyys selittää asenteista parhaiten oppilaan kuulumista parhaiden osaajien joukkoon yhdeksännellä vuosiluokalla.

\subsection{Kouluun liittyvät tekijät}

Jotta kyvykkyys, motivaatio ja minäpystyvyys voivat kehittyä, täytyy oppilaalle tarjottujen mahdollisuuksien vastata hänen potentiaaliaan (Leikin, 2014). Winner (2000) sekä Phillips ja Lindsay (2006) näkevät, että sopivilla haasteilla koulussa on suuri vaikutus erityisesti motivaatioon. Korkean motivaation saavuttamiseksi opiskelijat tarvitsevat vakautta, psykososiaalista tukea ja haasteita kognitiivisella tasolla (Ryan \& Deci, 2000). Lisäksi mielekkäät oppimistilanteet ovat yhteydessä minäpystyvyyden vaalimiseen ja alisuoriutumisen välttämiseen (Colangelo ym., 1993; McCoach \& Siegle, 2003).

Oppimistilanteet liittyvät vallitsevaan ympäristöön, jossa oppiminen tapahtuu. Voidaan puhua esimerkiksi luokkarakenteesta (classroom structure) (Ames, 1992) ja 
luokkailmapiiristä (Chionh \& Fraser, 2009). Luokkarakenne liittyy opetukseen ja siihen, miten opettaja suunnittelee tehtävät, ohjaa oppimistapahtumaa ja arvioi oppilaiden edistymistä. Itävaltalaistutkimuksen (Lüftenegger ym., 2015) mukaan koulussa erinomaisesti menestyvät 15-vuotiaat nuoret kokivat keskitasoa heikompia osaajia enemmän autonomiaa ja kokivat saaneensa enemmän taitotasonsa mukaisia oppimistehtäviä ja osallistuneensa aktiivisemmin opiskelua koskevaan päätöksentekoon. Luokan ilmapiirin nähdään liittyvän opiskelijoiden yhteenkuuluvuuden tunteeseen ja sen on havaittu olevan positiivinen ennustaja saavutuksille (Chionh \& Fraser, 2009). On kuitenkin hyvä muistaa, että jokaisen oppilaan yksilölliset tekijät vaikuttavat siihen, miten oppilas kokee opetustilanteen ja mitä hän oppii opetustilanteen aikana (Metsämuuronen, 2013).

Kansallisesti tarkasteltuna oppilasta aktivoivien menetelmien nähdään tuottavan parhaita oppimistuloksia. Oppimista ja opetusta ohjaa Perusopetuksen opetussuunnitelman perusteet, joka pohjautuu konstruktivistiseen oppimiskäsitykseen, jossa oppiminen ymmärretään yksilölliseksi ja yhteisölliseksi tietojen ja taitojen rakennusprosessiksi (Opetushallitus, 2004, s. 18). Uusissa opetussuunnitelman perusteissa korostetaan, että oppilas on aktiivinen toimija ja hän oppii asettamaan tavoitteita ja ratkaisemaan ongelmia sekä itsenäisesti että muiden kanssa (Opetushallitus, 2014, s. 17). Yleisesti muun muassa opettajien pitkän koulutuksen ja ammattitaidon on todettu olevan PISA-menestyksen selittäviä tekijöitä (Kansanen, 2003; Niemi, 2011; Niemi \& Jakku-Sihvonen, 2011; Sahlberg, 2011).

Hannula ja Oksanen (2013) ovat selvittäneet opetuksellisten tekijöiden yhteyttä matematiikan osaamiseen kansallisessa pitkittäisanalyysissä. Tulosten mukaan tärkeimpiä osaamista kehittäviä opetuksellisia tekijöitä olivat vähäinen oppilaiden osallistaminen tavoitteiden asetteluun ja arviointiin, oppilaiden toistensa neuvominen, mahdollisuus saada luokkaan toinen opettaja ja opettajan kyvykkyys oppilaiden käyttäytymisen hallinnassa (Hannula \& Oksanen, 2013). Myös kotitehtävien runsaammalla määrällä on havaittu olevan selkeä positiivinen yhteys matematiikan osaamiseen (Mattila \& Rautopuro, 2013). Toisella asteella keskeinen osaamista selittävä tekijä oli se, kuinka usein opiskelijat kokivat opiskeltavien asioiden tulevan selväksi. Parhaita oppimistuloksia saatiin ryhmässä, jossa opettajajohtoisuuteen yhdistyy eriyttäminen taitotason mukaisesti ja saatujen tulosten järkevyyttä pohdittiin (Metsämuuronen, 2017). Saarinen (2020) analysoi PISA-aineistoista vuosina 2003-2015 käytössä olleiden opetusmenetelmien yhteyttä 
15-vuotiaiden suomalaisten osaamiseen ja havaitsi, että itseohjautuvuutta edellyttävät menetelmät olivat yhteydessä heikompiin oppimistuloksiin ja opettajalähtöisten menetelmien käyttö korkeampiin oppimistuloksiin. Myös kansallisessa matematiikan oppimistuloksia mittaavassa tutkimuksessa (Metsämuuronen, 2010) havaittiin, että parhaatkin oppilaat hyötyivät opettajajohtoisesta opetuksesta ja konkreettisten havaintovälineiden käytöstä 6 . vuosiluokalle tultaessa.

Koulussa viihtyminen, koulukiusaaminen ja työrauhaan liittyvät tekijät vaikuttavat osaltaan oppimiseen koulussa. Metsämuurosen (2017) mukaan koulukiusaaminen, luokan työrauhaongelmat ja heikko viihtyminen koulussa estävät osaamisen kasvua erityisesti yläkoulussa. Se, että oppilaat neuvovat toisiaan, parantaa keskitasoa parempien osaajien oppimistuloksia verrattuna keskitasoa heikompiin osaajiin.

\subsection{Kotitaustaan liittyvät tekijät}

Yksilöllisten ja kouluun liittyvien tekijöiden lisäksi oppilaan käyttäytymistä ohjaavat yksilön kotiin ja perheeseen liittyvät tekijät, joista tässä luvussa tarkastellaan kielitaustaa, sosioekonomista taustaa ja kodin antamaa tukea matematiikan opiskeluun.

Kansallisissa oppimistulosarvioinneissa erot suomen- ja ruotsinkielisten koulujen oppilaiden välillä kaventuvat ylemmillä luokka-asteilla, kun eroa osaamisessa suomenkielisten oppilaiden hyväksi on ollut havaittavissa jonkin verran alakoulun luokka-asteilla (Metsämuuronen, 2010; 2017). Osalla oppilaista kotikieli on muu kuin suomi tai ruotsi ja osa heistä opiskelee suomea tai ruotsia toisena kielenä oppimäärän mukaan. Kansallisen matematiikan osaamista selvittävän tutkimuksen mukaan kotikielenään muuta kuin suomea tai ruotsia puhuvien oppilaiden osaaminen oli selvästi heikompaa kuin suomen- tai ruotsinkielisten oppilaiden osaaminen 6. ja 9. luokalla (Räsänen ym., 2010). Yhdeksännellä luokalla oppilaiden joukossa, jossa kotikieli oli muu kuin suomi, oli yli kolminkertainen määrä heikoiksi luokiteltuja oppilaita (Räsänen \& Närhi, 2013). Hotulainen ja kanssakirjoittajat (2016) ovat tutkineet metropolialueen nuorten eriytyviä kehityspolkuja yläkoulun aikana ja heidän toisen asteen valintoja. Tutkimustulosten mukaan maahanmuuttajatausta on yhteydessä heikompaan lähtötasoon, mutta ei osaamisen kehitykseen yläkoulun aikana. Lähtötasoerot maahanmuuttajataustaisten ja 
kantaväestöön kuuluvien oppilaiden välillä selittyvät vanhempien koulutustaustan ja suomen kielen osaamisen eroilla (Hotulainen ym., 2013).

Oppilaan sosioekonomisen taustan on monissa tutkimuksissa todettu olevan yhteydessä osaamiseen ja selittävän matematiikan osaamisen eroja (mm. SuárezÁlvarez ym., 2014; Välijärvi, 2017). Sosioekonominen status määritellään eri tavoin ja määrittelyssä käytetään vanhempien tulo-, koulutus ja ammattitietoja. Ei ole olemassa yhtä yleisesti hyväksyttyä tapaa mitata sosioekonomista statusta (APA, 2007, s. 5; Bradley \& Corwyn, 2002). Vanhempien koulutusta pidetään kuitenkin yhtenä keskeisistä sosioekonomisen statuksen osatekijöistä ja sitä on käytetty oppimistulosarvioinneissa yksinkertaisena sosioekonomisen statuksen indikaattorina. Vanhempien ylioppilastutkinto on selittänyt kansallisissa tutkimuksissa selvästi osaamisen eroja eri oppianeissa ( $\mathrm{mm}$. Ouakrim-Soivio \& Kuusela, 2012; Hildén \& Rautopuro, 2014; Härmälä ym., 2014; Metsämuuronen, 2013; Kuukka \& Metsämuuronen, 2016). Vanhempien koulutuksella näyttää olevan keskeinen rooli matematiikan osaamisen kehittymisessä jo 3. luokalta lähtien toisen asteen koulutukseen asti (Metsämuuronen, 2013; 2017).

Hiltunen ja Nissinen (2018) ovat tutkineet PISA 2015 -tutkimuksessa erinomaisesti menestyneitä suomalaisia matematiikan osaajia. Heidän mukaansa perheen korkealla sosioekonomisella statuksella on merkitsevä yhteys erinomaiseen osaamiseen ja erityisesti isän korkealla koulutustasolla on merkitystä. Välijärven (2017) mukaan sosioekonomisella taustalla on vahva yhteys myös oppilaan suoritusmotivaatioon. Oppilailla, joilla on korkeampi sosioekonominen tausta, on parempi suoritusmotivaatio kuin niillä, joilla on matalampi sosioekonominen tausta. Välijärven (2017) mukaan korkean sosioekonomisen taustan nuoret saavat enemmän tukea koulunkäyntiinsä ja tämä on yhteydessä parempiin oppimistuloksiin.

Sosioekonomisen taustan lisäksi tutkimukset ovat osoittaneet, että kodin antaman tuen merkitys oppimiselle on keskeinen. Vanhemman antama tuki, asenteet ja vaikutteet heijastuvat lapseen. Jos vanhemmat antavat lapselle tukea ja ovat kiinnostuneita lapsen koulunkäynnistä, lapsi menestyy paremmin koulussa (Robinson \& Harris, 2014; Schneider, 1993). Kodin tuen yhteyttä osaamiseen on tutkittu toisen asteen opiskelijoiden osalta kansallisessa matematiikan arvioinnissa (Metsämuuronen, 2017). Tutkimustulosten mukaan kodin tuki selittää merkitsevästi osaamista sekä lukiossa että ammatillisessa koulutuksessa. Lukiossa yhteys näkyy voimakkaammin: mitä enemmän opiskelija koki saavansa tukea opiskeluun, sitä korkeampaa hänen osaamisensa oli. Ero osaamisessa kodin tukea saaneiden 
ääriryhmien välillä vastasi kahden vuoden opintoja. Ammatillisessa koulutuksessa vaikutus näkyi nuin, että tukea erittäin vähän saaneiden opiskelijoiden osaamisen taso oli merkitsevästi matalampaa kuin muissa ryhmissä. Merkityksellisenä tekijänä kodin tuesta lukiossa osoittautui se, pitävätkö vanhemmat matematiikkaa oppiaineena tärkeänä ja ammatillisessa koulutuksessa se, arvostavatko vanhemmat koulutusta. Toki vanhempien ylioppilastaustalla saattaa olla merkitystä kodin antaman tuen kanssa, koska heillä on paremmat lähtökohdat esimerkiksi tukea lasta koulutehtävissä.

\section{Matematiikan osaaminen toisen asteen koulutuksessa}

Suomalainen koulujärjestelmä on kansainvälisesti verraten melko yhdenmukainen kaikille yhteisen perusopetuksen ajan. Sen jälkeen koulutus eriytyy lukioon ja ammatilliseen koulutukseen, jotka molemmat mahdollistavat etenemisen korkeaasteen koulutukseen. Käytännössä kuitenkin usein ammatillisesta koulutuksesta siirrytään suoraan työelämään ja lukiokoulutuksesta korkeakouluihin. Kalalahden, Zacheuksen, Laaksosen ja Jahnukaisen (2019) mukaan siirtymä toiselle asteelle sisältää tasa-arvoon liittyviä haasteita. Toisen asteen koulutukseen hakeminen ja siellä opiskelu sekä valmistuminen ovat yhteydessä opiskelijan perhetaustaan, koulumenestykseen ja koulunkäynnin sujuvuuteen.

Peruskoulun päättöarvosanat ovat keskeisessä asemassa toisen asteen koulutuspaikan valinnassa ja sinne pääsemisessä. Keskiarvoissa on huomattavia eroja koulujen ja kuntien välillä. Ouakrim-Soivio (2013) ja Hotulainen ym. (2017) ovat tutkimuksissaan osoittaneet, että opettajat suhteuttavat antamansa arvosanat muiden oppilaidensa osaamistasoon eivätkä valtakunnallisiin kriteereihin. Mahdollisuudet menestyä toisen asteen koulutuksessa eivät ole yhdenvertaisia (Hotulainen ym., 2017). Erot peruskoulun päättöarvosanoissa tyttöjen ja poikien välillä ja eri oppiaineissa uhkaavat oppilaiden yhdenvertaista kohtelua toiselle asteelle siirryttäessä. Tähän on puututtu, ja Opetushallitus on laatinut kriteerit perusopetuksen päättöarviointiin kaikissa oppiaineissa. Kriteerien mukaiset päättöarvosanat annetaan kaikissa oppiaineissa koko ikäluokalle keväällä 2022. On kuitenkin huomioitava, että päättöarvosanat eivät vastaa toisiaan eri lukioiden välillä. Osaamistasoltaan matalampien oppilaitosten parhaita arvosanoja saaneet opiskelijat saattavat olla heikompia kuin korkeimpia tuloksia saaneiden lukioiden heikoimpia arvosanoja saaneet opiskelijat (Metsämuuronen, 2017). 
Matematiikan opintojen määrät ja tavoitteet ovat erilaiset lukiossa ja ammatillisessa koulutuksessa. Lukiossa matematiikan pitkän oppimäärän opinnoissa on kymmenen pakollista kurssia ja kolme syventävää kurssia. Lisäksi lukiot voivat tarjota näiden lisäksi muitakin kursseja. Lyhyen oppimäärän opinnoissa on kuusi pakollista ja kaksi syventävää kurssia (Opetushallitus, 2003). Matematiikan osaamista toisen asteen lopussa kuvaavien tutkimustulosten mukaan lyhyen matematiikan vähimmäiskurssimäärän suorittaneet opiskelijat säilyttävät 9. luokan osaamisen tason, ja pitkän oppimäärän suorittaminen kasvattaa osaamista merkittävästi (Metsämuuronen, 2017). Ylioppilastutkintojärjestelmä mahdollistaa, että pitkän matematiikan oppimäärän opiskellut voi kirjoittaa lyhyen matematiikan ylioppilaskokeen.

Ammatillisessa koulutuksessa ei ole lukiokoulutusta vastaavaa kurssijärjestelmää. Metsämuurosen (2017) mukaan ammatillisen koulutuksen matematiikan sisällöt vastaavat lukiokoulutuksen lyhyen matematiikan kursseja Lausekkeet ja yhtälöt ja Geometria tai pitkän matematiikan kurssia Funktiot ja yhtälöt ja toista seuraavista kursseista: Polynomifunktiot tai Geometria. Ammatillisen koulutuksen tutkintojen perusteissa (Opetushallitus, 2009) korostetaan matematiikan taitojen käyttämistä ja soveltamista ammattiin liittyvissä tilanteissa. Metsämuurosen (2017) mukaan ammatillinen koulutus tarjoaa mahdollisuuden saavuttaa lukion matematiikan lyhyttä oppimäärää vastaavan osaamisen tason, mutta matematiikan osaaminen jää usein vähäiseksi, mikä on keskeinen ongelma jatko-opintojen kannalta.

\section{Tutkimuskysymykset}

Tutkimuksessa selvitetään yhdeksännen vuosiluokan matematiikan parhaiden osaajien yksilöön liittyvien tekijöiden, kouluun liittyvien tekijöiden ja kotitaustaan liittyvien tekijöiden yhteyttä toisen asteen koulutusvalintaan ja osaamisen kehittymiseen toisen asteen opintojen aikana.

1. Mitkä tekijät selittävät yhdeksännen vuosiluokan matematiikan parhaiden osaajien hakeutumista ammatilliseen koulutukseen ja lukioon?

2. Miten yhdeksännen vuosiluokan matematiikan parhaiden osaajien matematiikan osaamistaso muuttuu toisen asteen opintojen aikana?

(a) Miten suuri osa yhdeksännen vuosiluokan matematiikan parhaista osaajista on parhaita osaajia myös toisen asteen lopussa? 
(b) Mitkä tekijät selittävät joidenkin yhdeksännen vuosiluokan parhaiden osaajien putoamista parhaiden osaajien joukosta toisen asteen lopussa?

\section{Tutkimusmenetelmät}

\subsection{Tutkimuskohde}

Tutkimuksessa käytettävä aineisto on Opetushallituksen ja Kansallisen koulutuksen arviointikeskuksen (Karvin) keräämä pitkittäisaineisto, jossa samaan ikäluokkaan kuuluvien oppilaiden matematiikan osaamisesta, asenteista ja taustatekijöistä on kerätty tietoa vuosien 2005-2015 aikana oppilaiden ollessa kolmannella, kuudennella ja yhdeksännellä vuosiluokalla sekä toisen asteen päättyessä. Aineisto on kansallisesti edustava ja siinä on huomioitu muun muassa maantieteellinen jakauma.

Tutkimusaineisto käsittää kaikkiaan 3896 oppilasta, joista erityisen tarkastelun kohteena ovat matematiikan parhaat osaajat. Parhaat osaajat määritetään yhdeksännen vuosiluokan kokeessa menestymisen perusteella niin, että heidän saamansa kokonaispistemäärä on vähintään 1,5 hajontayksikköä kokeen keskiarvoa korkeampi. Vertailuryhmänä tutkimuksessa ovat hyvät osaajat ja keskitason osaajat. Hyvien osaajien kokonaispistemäärä on 1,0-1,5 hajontayksikköä kokeen keskiarvoa korkeampi ja keskitason osaajien kokonaispistemäärä on enintään 1,o hajontayksikön päässä kokeen keskiarvosta. Heikoimmat osaajat on rajattu tarkastelusta pois tässä tutkimuksessa.

Yhdeksännen vuosiluokan kokeessa parhaiten menestyneitä oppilaita on yhteensä 292 (7,5 \% koko otoksesta). Poikia on 187 (64,0 \%) ja tyttöjä 105 (36,0 \%). Taulukossa 1 on tietoa parhaiden, hyvien ja keskitason osaajien koepisteistä yhdeksännellä vuosiluokalla.

Taulukko 1. Koepisteet yhdeksännellä vuosiluokalla

\begin{tabular}{lllll}
\hline Koepisteet & $\begin{array}{l}\text { Parhaat osaajat } \\
(\mathbf{n = 2 9 2 )}\end{array}$ & $\begin{array}{l}\text { Hyvät osaajat } \\
(\mathbf{n}=\mathbf{3 2 6})\end{array}$ & $\begin{array}{l}\text { Keskitason osaajat } \\
(\mathbf{n}=\mathbf{2 6 5 8})\end{array}$ & $\begin{array}{l}\text { Koko otos } \\
(\mathbf{n}=\mathbf{3 8 9 6})\end{array}$ \\
\hline Keskiarvo & 722,7 & 641,5 & 506,9 & 510,5 \\
Min. & 673,3 & 617,1 & 409,6 & 131,0 \\
Max. & 1029,5 & 665,1 & 616,1 & 1029,5 \\
Keskihajonta & 49,8 & 14,5 & 57,2 & 106,3 \\
\hline
\end{tabular}




\subsection{Matematiikan koetehtävät tutkimuksessa}

Kansallisissa arvioinneissa olevat matematiikan kokeet mittaavat opetussuunnitelmien toteutumista eli kokeiden sisältöalueet on valittu perusopetuksen ja toisen asteen opetussuunnitelmien perusteiden mukaan. Aineisto perustuu perusopetuksen ja lukion opetussuunnitelman perusteisiin (Opetushallitus, 2003; 2004) sekä ammatillisen tutkinnon koulutuksen perusteisiin (Opetushallitus, 2009). Perusteet on päivitetty myöhemmin tämän aineiston keräämisen jälkeen. Kansallisten kokeiden tehtävät, arvosteluperusteet ja pisteytysohjeet laaditaan yleisesti asiantuntijaryhmissä. Lisäksi tehtäväsarjojen laadun arvioinnissa käytetään asiantuntijoita ja esitestausta. Tehtäväsarjoissa on vaikeustasoltaan helppoja, keskivaikeita ja vaikeita osioita (Metsämuuronen, 2009).

Matematiikan arviointi kohdistuu matematiikan kokonaisosaamiseen, joka koostuu eri osa-alueista taulukossa 2 esitetyn jaottelun mukaan.

Taulukko 2. Matematiikan osa-alueet eri vuosiluokkien kokeissa

\begin{tabular}{lllll}
\hline & Luokka-aste & $\begin{array}{l}\text { Osioiden } \\
\text { määrä }\end{array}$ & $\begin{array}{l}\text { Maksimi- } \\
\text { pistemäärä }\end{array}$ & $\begin{array}{l}\text { Reliabiliteetti } \\
(\boldsymbol{\alpha})\end{array}$ \\
\hline Kokonaisosaaminen & $3 . \mathrm{lk}$ & 38 & 44 & 0,86 \\
& $6 . \mathrm{lk}$ & 39 & 52 & 0,85 \\
& $9 . \mathrm{lk}$ & 681 & 841 & 0,94 \\
& lukio & 28 & 52 & 0,87 \\
& ammatillinen & 30 & 46 & 0,84 \\
\hline Luvut, laskutoimitukset ja & $3 . \mathrm{lk}$ & 22 & 24 & 0,81 \\
algebra & $6 . \mathrm{lk}$ & 21 & 28 & 0,78 \\
& $9 . \mathrm{lk}$ & 36 & 40 & 0,88 \\
& lukio & 3 & 3 & 0,27 \\
& ammatillinen & 3 & 3 & 0,26 \\
\hline Geometria & $3 . \mathrm{lk}$ & 10 & 14 & 0,67 \\
& $6 . \mathrm{lk}$ & 10 & 14 & 0,66 \\
& $9 . \mathrm{lk}$ & 16 & 22 & 0,83 \\
& lukio & 7 & 14 & 0,73 \\
\hline Tietojen käsittely, tilastot ja & ammatillinen & 7 & 14 & 0,65 \\
todennäköisyys & $3 . \mathrm{lk}$ & 6 & 6 & 0,55 \\
& $6 . \mathrm{lk}$ & 8 & 10 & 0,47 \\
& $9 . \mathrm{lk}$ & 9 & 2 & 0,61 \\
& lukio & 2 & 5 & 0,34 \\
\hline Algebra & ammatillinen & 5 & 8 & 0,56 \\
\hline Funktiot & lukio & 6 & 8 & 0,71 \\
& ammatillinen & 6 & 31 & 0,71 \\
\hline
\end{tabular}

1 Sisältää viisi Funktiot-osa-alueen laskua 
Toisella asteella toteutetuista matematiikan kokeista tehtiin kaksi versiota, toinen lukioon ja toinen ammatilliseen koulutukseen. Kokeiden pohjana käytettiin yhdeksännen vuosiluokan koetta niin, että 78 prosenttia tehtävistä oli samoja tehtäviä. Joitain tehtäviä otettiin myös kuudennen luokan ja kolmannen luokan kokeista. Lisäksi ammatillisen koulutuksen kokeessa oli kaksi tehtävää vuoden 1998 ammatillisen koulutuksen matematiikan kansallisesta kokeesta ja yksi lyhyen matematiikan ylioppilastehtävä. (Metsämuuronen, 2017).

Jotta eri vuosien kokeiden ja eri koeversioiden tuloksia voidaan vertailla, täytyy pistemäärät vertaistaa eli saattaa yhteismittalisiksi. Vertaistamisessa on käytetty osiovasteteoriaan (Item Response Theory) perustuvaa IRT-mallitusta (Rasch, 1960; Lord \& Novick, 1968). Opetushallituksen ja Karvin pitkittäisvertailujen (esim. Metsämuuronen, 2006; 2013) lisäksi vertaistamista on käytetty myös kansainvälisissä PISA- (esim. OECD, 2007; 2010; Hautamäki ym. 2008) ja TIMMStutkimuksissa (esim. TIMSS, 2009). IRT-mallituksessa oppilaan osaamisen taso ja tehtävän vaikeustaso saatetaan vastaamaan toisiaan. Eri koeversioissa olevien osioiden vaikeustasoa voidaan arvioida linkkitehtävien avulla. Toisin sanoen eri koeversioihin määritetään linkkitehtäviä eli identtisiä tehtäviä, joiden avulla selvitetään, kuinka paljon osaamista tarvitaan, että osiot voidaan ratkaista ja tämän jälkeen kuinka paljon osaamista tarvitaan kunkin pistemäärän saavuttamiseen koko kokeessa ja osamittareissa. Tässä aineistossa vertaistamiseen on valittu perustasoksi 9. luokan koe ja opiskelijoita verrataan siinä keskitasoisesti menestyneeseen oppilaaseen (ks. tarkemmin mm. Metsämuuronen, 2017, s. 213-214).

Tutkimuksessa osaamista kuvaavat pistemäärät esitetään samalla asteikolla kuin PISA- ja TIMSS-tutkimuksissa. Tässä asteikossa 9. vuosiluokalla osaamiseltaan keskitason oppilas saa 500 pistettä ja keskihajonta on 100 pistettä (ks. Metsämuuronen 2017, s. 214-215). Osaamisessa tapahtunutta muutosta tarkastellaan kokonaispistemäärässä tapahtuneen muutoksen mukaan. Toisen asteen koe on linkkitehtävillä saatu vertailukelpoisiksi ja kokeen vertaistetut pistemäärät ovat suoraan verrattavissa yhdeksännen luokan osaamistasoon.

\subsection{Asenteiden kartoittaminen tutkimuksessa}

Matematiikan osaamista mittaavien kokeiden lisäksi oppilailta on koottu tietoja asenteista matematiikkaa kohtaan. Asenteiden kartoittamisessa käytetään 15 osion Likert-asteikollista mittaria, joka pohjautuu laajalti käytettyyn Fenneman ja Shermanin (1976) matematiikka-asennemittariin. Kolmannella vuosiluokalla 
käytettiin lyhennettyä versiota standardimittarista ja sanamuotoja muokattiin konkreettisemmiksi. Mukana ei ollut oppiaineen hyödylliseksi kokemisen osa-aluetta, koska kysymykset liittyivät pitkälti jatko-opintoihin ja työelämään. Lisäksi asteikko oli neliportainen muuten viisiportaisena käytetyn Likert-asteikon sijaan. Kuudennella ja yhdeksännellä luokalla sekä toisella asteella käytetyt mittarit olivat keskenään samanlaiset, mutta yhdeksännellä vuosiluokalla ja toisella asteella kerättiin tietoa myös oppilaiden matematiikka-ahdistuksesta. Lisäksi toisella asteella on kartoitettu oppilaiden tunnetiloja (innostus, kiinnostus, tylsyys, pitäminen, turhautuminen, viha, ahdistus, avuttomuus, tyytyväisyys) matematiikan opiskelussa. Tunnetiloista on muodostettu kaksi faktoria: positiiviset ja negatiiviset tunnetilat. (Metsämuuronen \& Tuohilampi, 2017).

Asenteita on kartoitettu eri väittämin taulukossa 3 näkyvien osa-alueiden mukaan.

Taulukko 3. Asennemittareiden osa-alueet eri vuosiluokilla

\begin{tabular}{|c|c|c|c|c|}
\hline & Luokka-aste & Osioiden määrä & $\begin{array}{l}\text { Maksimi- } \\
\text { pistemäärä }\end{array}$ & $\begin{array}{l}\text { Reliabiliteetti } \\
(\alpha)\end{array}$ \\
\hline \multirow[t]{5}{*}{ Kokonaisasenne $^{1}$} & $3.1 \mathrm{k}$ & 8 & 32 & 0,86 \\
\hline & 6. Ik & 10 & 50 & 0,88 \\
\hline & 9. $1 \mathrm{k}$ & 10 & 50 & 0,91 \\
\hline & lukio & 15 & 60 & 0,92 \\
\hline & ammatillinen & 15 & 60 & 0,91 \\
\hline \multirow{5}{*}{$\begin{array}{l}\text { Käsitys itsestä } \\
\text { matematiikan osaajana } \\
\text { (OSAA) }\end{array}$} & 3. Ik & 4 & 16 & 0,79 \\
\hline & 6. Ik & 5 & 25 & 0,82 \\
\hline & 9. Ik & 5 & 25 & 0,88 \\
\hline & lukio & 5 & 20 & 0,86 \\
\hline & ammatillinen & 5 & 20 & 0,87 \\
\hline \multirow{5}{*}{$\begin{array}{l}\text { Matematiikasta pitäminen } \\
\text { (PITÄÄ) }\end{array}$} & 3. Ik & 4 & 16 & 0,88 \\
\hline & 6. $1 \mathrm{k}$ & 5 & 25 & 0,89 \\
\hline & 9. Ik & 5 & 25 & 0,90 \\
\hline & lukio & 5 & 20 & 0,92 \\
\hline & ammatillinen & 5 & 20 & 0,91 \\
\hline \multirow{3}{*}{$\begin{array}{l}\text { Matematiikan koettu } \\
\text { hyödyllisyys } \\
\text { (HYÖTY) }\end{array}$} & $9.1 \mathrm{k}$ & 5 & 25 & 0,53 \\
\hline & lukio & 5 & 20 & 0,83 \\
\hline & ammatillinen & 5 & 20 & 0,83 \\
\hline \multirow[t]{3}{*}{ Matematiikka-ahdistus } & 9. Ik & 4 & 20 & 0,71 \\
\hline & lukio & 3 & 13 & 0,76 \\
\hline & ammatillinen & 3 & 13 & 0,76 \\
\hline \multirow{2}{*}{$\begin{array}{l}\text { Positiiviset tunnetilat } \\
\text { matematiikan opiskelussa }\end{array}$} & lukio & 9 & 36 & 0,90 \\
\hline & ammatillinen & 9 & 36 & 0,90 \\
\hline
\end{tabular}

1 Kokonaisasenteessa 3. ja 6. luokalla mukana OSAA- ja PITÄÄ-osa-alueet 


\subsection{Taustamuuttujat}

Matemaattista osaamista selitetään erilaisilla muuttujilla, joita on selvitetty oppilaille suunnattujen taustakyselyiden avulla osaamista kartoittavien kokeiden yhteydessä. Kuviossa 1 on malli, jossa on esitetty taustamuuttujat, joiden yhteyttä osaamiseen ja osaamisen muutokseen selvitetään tässä tutkimuksessa. Malli on luotu mukaillen Metsämuurosen (2009) mallia, jossa oppimiseen, oppimistuloksiin ja oppimistulosten muutokseen vaikuttavia tekijöitä tarkastellaan kaikkiaan kahdeksasta eri näkökulmasta.

Tässä tutkimuksessa mallissa ovat mukana yksilöön liittyvät tekijät, kouluun liittyvät tekijät ja opiskelijan kotitaustaan liittyvät tekijät. Yksilöön liittyvät tekijät jakautuvat osaamiseen, asenteisiin ja koulutusvalintoihin liittyviin tekijöihin sekä sukupuoleen. Kouluun liittyvät tekijöihin kuuluvat opetuksen pedagogiset ratkaisut ja koulun vertaisryhmään liittyvät tekijät. Kotitaustaan liittyvät tekijät käsittävät kotikielen, vanhempien lukiokoulutuksen ja kodin antaman tuen matematiikan opiskeluun.

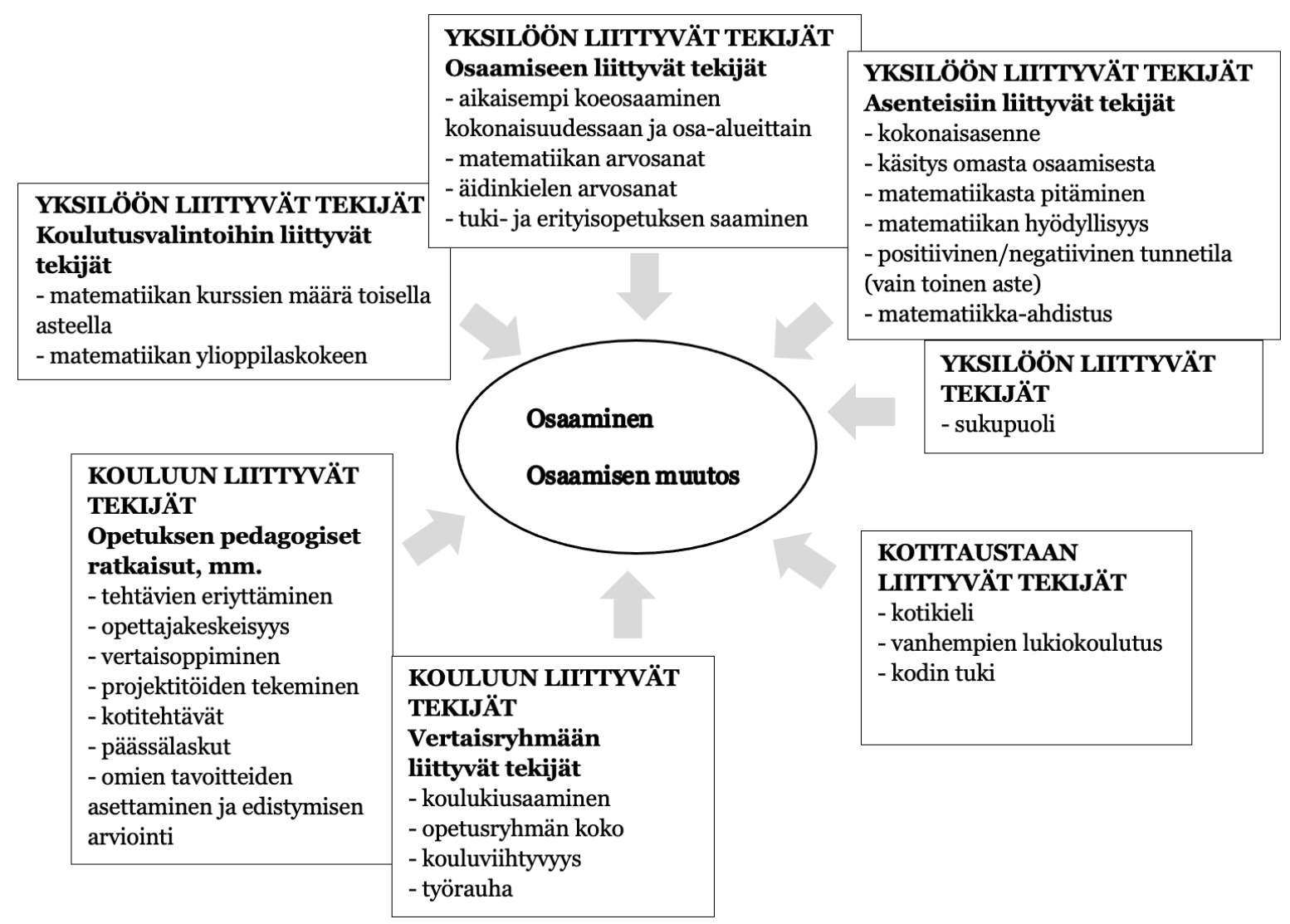

Kuvio 1. Taustamuuttujien käsitteellinen malli 


\subsection{Puuttuvien havaintojen mallittaminen aineistossa}

Pitkittäisaineistossa on puuttuvaa tietoa opiskelijoista, joilta ei ole saatu kerättyä tietoa kaikilta neljältä eri mittauskerralta. Tällöin yksittäistä opiskelijaa koskevia puuttuvia havaintoja on mallitettu muiden mittaustulosten avulla hyödyntäen lineaarista ja epälineaarista regressioanalyysiä. Vuoden 2008 eli 6. vuosiluokan aineistossa oli vähiten puuttuvia tapauksia. Kuuden puuttuvan tapauksen arvot interpoloitiin epälineaarisesti käyttämällä 3. ja 9. vuosiluokan sekä toisen asteen koulutuksen arvoja. Mallituksessa hyödynnettiin myös niin sanotun o. luokan tietoa, joka oli mallinnettu asiantuntijamenettelynä niin, että arvioitiin, millaisista 3. luokan tehtävistä koulun aloittavat oppilaat olisivat todennäköisesti suoriutuneet. Kuviossa 2 on esitetty kahden oppilaan puuttuvan tiedon korvaaminen 6 . vuosiluokalla. Vuoden 2012 eli 9. vuosiluokan datasta puuttui 128 tapauksen arvot. Ne interpoloitiin lineaarisesti hyödyntäen 6. vuosiluokan ja toisen asteen koulutuksen arvoja. Vuoden 2005 eli 3. vuosiluokan datasta puuttui 625 tapauksen arvot, jotka mallinnettiin lineaarisesti tietäen 6. ja 9. vuosiluokan mittaustulokset. Ennuste oli kohtalainen, vaikka 3. luokan osaaminen ei ole yhtä vakaata kuin myöhemmillä luokka-asteilla.

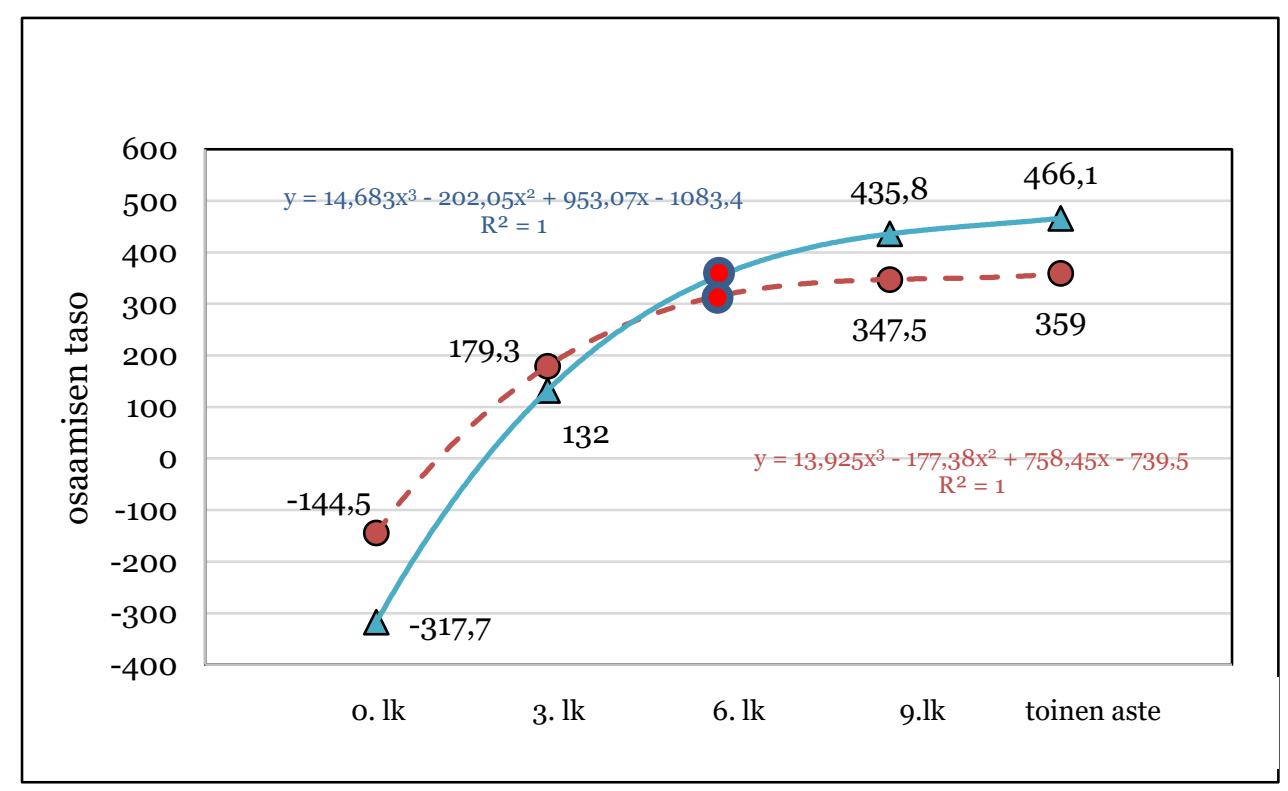

Kuvio 2. Kahden oppilaan puuttuvan tiedon korvaaminen 6. luokan aineistossa

Vuoden 2015 puuttuvien arvojen laskeminen oli monimutkaisempaa kuin puuttuvien arvojen laskeminen aikaisempien vuosien osalta. Ensinnäkin puuttuvia tapauksia oli eniten vuoden 2015 osalta. Koko aineistosta puuttuvia tapauksia oli 47,4 $\%(n=1846)$ ja parhaiden osaajien osalta 14,0 \% $(n=41)$. Puuttuvien tapausten 
suuren määrän vuoksi mallinnuksen tulos ei ole yhtä vakaa kuin vuosien 2008ja 2012 mallinnus. Viimeisen mittausvuoden mallinnus pystyttiin tekemään hyödyntäen opiskelijoiden rekisteritietoja suoritettujen matematiikan kurssien lukumäärästä, niiden arvosanoista ja matematiikan ylioppilaskirjoituksen tuloksista. Toiseksi mallinnus oli järkevää tehdä erikseen lukion ja ammatillisen koulutuksen opiskelijoille ja kolmanneksi kun lukion ja ammatillisen koulutuksen puolella opiskelijat jakautuivat eri alaryhmiin koulutusvalintojen suhteen, mallinnus oli järkevää tehdä myös eri alaryhmille erikseen.

Lukiossa opiskelijat ovat opiskelleet matematiikan pitkän (vähintään 12 kurssia) tai lyhyen oppimäärän (vähintään 7 kurssia). Lyhyen oppimäärän opiskelleista osa suorittaa matematiikan ylioppilaskokeen ja on opiskellut kursseja enemmän kuin vähimmäismäärän. Osa opiskelijoista ei kirjoita matematiikkaa ylioppilaskokeessa ja on suorittanut matematiikan kursseja vain vähimmäismäärän. Osaamistasojen erot näiden kolmen ryhmän välillä ovat tilastollisesti merkitseviä (Metsämuuronen, 2017; Metsämuuronen \& Tuohilampi, 2017). Puuttuvat arvot mallinnettiin näissä kolmessa ryhmässä erikseen. Lukioaineistossa 9. luokan tulos ennusti osaamista yksinään 57 \% $\left(R^{2}=0,57\right)$. Kun lisäksi tiedettiin lukion aikana suoritettujen matematiikan kurssien määrä, kokonaisselitysaste nousi 72 prosenttiin $\left(R^{2} A d j=0,72\right)$.

Ammatillisessa koulutuksessa opiskelijat suuntautuivat kahdeksalle opintoalalle (humanistiset tieteet ja koulutus, kulttuuri, yhteiskuntatieteet, liiketalous ja hallinto, luonnontieteet, tekniikka ja liikenne, luonnonvarat ja ympäristö, sosiaalipalvelut, terveys ja liikunta sekä matkailu, ravitsemus ja talous), joissa matematiikan tarve eroaa toisistaan huomattavasti ja joissa opiskelijoiden osaamistasot eroavat tilastollisesti merkitsevästi toisistaan (Metsämuuronen \& Salonen, 2017). Puuttuvat arvot mallinnettiin näissä ryhmissä erikseen. Mallinnuksessa käytettävää tietoa oli ammatillisessa koulutuksessa vähemmän, koska matematiikan kurssien lukumäärä, kolme, on kaikille sama. Viisi muuttujaa, osaaminen vuosina 2012, 2008 ja 2005, matematiikan kurssien keskiarvo ja ammatillisen koulutusyksikön keskimääräinen osaaminen, selittivät $63 \%$ ammatillisen oppilaitosten tuloksista $\left(R^{2} A d j=0,63\right)$. Koska vuoden 2015 aineistossa puuttuvia havaintoja on paljon, on toista astetta koskeviin tuloksiin syytä suhtautua myös kriittisesti. Puuttuvien havaintojen mallituksessa käytettyjen mallien selitysasteet olivat kuitenkin korkeita, joten ennusteet ovat riittävän tarkkoja uskottavien johtopäätösten tekemiseen. 


\subsection{Tulosten analysointi}

Tulosten kuvailussa käytetään perustunnuslukuja kuten frekvenssi- ja prosenttijakaumia sekä keskiarvo- ja keskihajontalukuja. Ryhmien välisiä eroja analysoidaan parametrisin testein kuten t-testillä ja yksisuuntaisella varianssianalyysillä.

Osaamista ja osaamisen muutosta selittäviä tekijöitä analysoidaan monimuuttujamenetelmin. Ensiksi keskeisten ennustekijöiden selvittämisessä käytetään päätöspuu-analyysia (decision tree analysis, DTA). Sen avulla voidaan eksploroida laajaa aineistoa ja selvittää muun muassa millaiset tekijät osoittavat oppilaan kuuluvan parhaiden osaajien joukkoon toisen asteen lopussa. Menetelmä löytää oleelliset muuttujat, jotka erottelevat ja luokittelevat selitettävää muuttujaa uskottavasti. Analyysissa käytettiin CHAID-algoritmia, joka etsii tilastollisesti samankaltaisia arvoja selittävän ja selitettävän muuttujan välillä. Algoritmi etsii ja luokittelee ryhmiä, joiden välinen ero on mahdollisimman suuri vertaamalla testien p-arvoja. Jos selittävä muuttuja on jatkuva, p-arvoja etsitään F-testin avulla. Jos muuttuja on järjestysasteikollinen, p-arvoa etsitään likelihood-ratio -testillä. Mikäli muuttuja on luokitteluasteikolliinen, p-arvoa etsitään khiin neliö- testillä tai likelihood-ratio -testillä (Kass, 1980; Metsämuuronen, 2003, 738-739; 2013, 56-57). Tässä tutkimuksessa menetelmää käytetään löytämään keskeisiä erottelevia tekijöitä eri osaajaryhmien välillä.

Toiseksi asiayhteyksien mallintamisessa ja osaamista ennustavien tekijöiden analysoinnissa hyödynnetään lineaarista regressioanalyysiä, jonka avulla saadaan muun muassa muuttujien selitysosuudet paremmin näkyviin. Regressioanalyysissa käytetään askeltavaa menettelyä (stepwise selection). Tabachnick ja Fidell (2007) kutsuvat menettelyä tilastollisiksi menettelyiksi (statistical regression), koska selittävät muuttujat valitaan malliin pelkästään tilastollisin perustein. Askeltavassa menettelyssä yhtälöön lisätään riippumattomia muuttujia yksi kerrallaan ja niitä voidaan myös poistaa, kun uusia paremmin selittäviä muuttujia tulee tilalle. Lopulliseen malliin jää selitysvoimaltaan tilastollisesti merkitsevät muuttujat (Pedhazur, 1982; Metsämuuronen, 2003; Tabachnick \& Fidell, 2007). Regressioanalyysin oletuksena on, että selittävät muuttujat eivät korreloi liian voimakkaasti toistensa kanssa. Selittävien muuttujien välistä voimakasta korrelointia, multikollineaarisuutta tutkitaan analyysin tekemisen yhteydessä. Regressioanalyysin tulokset esitetään niin, että muuttujat ovat analyysin esittämässä järjestyksessä. Mallissa ensimmäisenä esitetty muuttuja selittää selitettävän 
muuttujan vaihtelua parhaiten ja seuraavat muuttujat lisäävät mallin selitysastetta. Lineaarisen regressioanalyysin käytössä tulee ottaa huomioon, että muuttujien yhteydet eivät ole puhtaan lineaarisia. Havaittu vaikutus saattaa syntyä esimerkiksi muuttujan toisen ääripään voimakkaasta vaihtelusta (Metsämuuronen, 2009, s. 49).

\section{Tulokset}

Tuloksissa tarkastellaan ensin yhdeksännen vuosiluokan matematiikan parhaiden osaajien hakeutumista ammatilliseen koulutukseen ja lukioon ja sitä, mitkä tekijät selittävät valintaa. Sen jälkeen selvitetään, miten yhdeksännen vuosiluokan parhaiden osaajien osaaminen on muuttunut toisen asteen opintojen aikana ja mitkä tekijät selittävät osaamisen vaihtelua toisella asteella.

\subsection{Matematiikan parhaiden osaajien hakeutuminen toisen asteen koulutukseen}

Koska yhdeksännen vuosiluokan matematiikan parhaista osaajista vain 25 opiskeli ammatillisessa koulutuksessa, pidetään yhdeksännen vuosiluokan matematiikan hyvät osaajat tässä toisen asteen koulutusvalintaa selittävässä osiossa mukana. Näin ammatillisen koulutuksen ja lukiokoulutuksen välisestä erottelusta saadaan selkeämpi.

Selvä enemmistö parhaista sekä hyvistä osaajista opiskeli lukiossa (taulukko 4). Parhaista osaajista ja hyvistä osaajista noin joka kymmenes opiskeli ammatillisessa koulutuksessa.

Taulukko 4. Yhdeksäsluokkalaisten opiskelu ammatillisessa koulutuksessa tai lukiossa

\begin{tabular}{lllll}
\hline & $\begin{array}{l}\text { parhaat osaajat } \\
(\mathbf{n = 2 9 2 )}\end{array}$ & $\begin{array}{l}\text { hyvät osaajat } \\
(\mathbf{n}=\mathbf{3 2 6})\end{array}$ & $\begin{array}{l}\text { keskitason } \\
\text { osaajat (n } \\
\mathbf{2 6 5 8 )}\end{array}$ & $\begin{array}{l}\text { koko otos } \\
(\mathbf{n}=\mathbf{3 8 9 6})\end{array}$ \\
\hline $\begin{array}{l}\text { ammatillinen } \\
\text { koulutus }\end{array}$ & $8,6 \%$ & $12,9 \%$ & $45,1 \%$ & $46,2 \%$ \\
$\begin{array}{l}\text { lukio } \\
\text { kaksoistutkinto }\end{array}$ & $91,4 \%$ & $86,9 \%$ & $54,1 \%$ & $53,8 \%$ \\
\hline
\end{tabular}

Enemmistö parhaista ja hyvistä osaajista suoritti pitkän matematiikan ylioppilaskokeen toisen asteen lopussa (taulukko 5). Tuloksissa keskitytään jatkossa kuitenkin tarkastelemaan koulutusvalintaa vain ammatillisen koulutuksen ja 
lukiokoulutuksen välillä eikä huomioida erikseen matematiikan opintojen laajuutta toisella asteella.

Taulukko 5. Yhdeksäsluokkalaisten matematiikan opintojen laajuus ylioppilaskoetiedon mukaan

\begin{tabular}{lllll}
\hline & $\begin{array}{l}\text { parhaat osaajat } \\
(\mathbf{n}=\mathbf{2 9 2})\end{array}$ & $\begin{array}{l}\text { hyvät osaajat } \\
(\mathbf{n}=\mathbf{3 2 6})\end{array}$ & $\begin{array}{l}\text { keskitason } \\
\text { osaajat }(\mathbf{n}= \\
\mathbf{2 6 5 8 )}\end{array}$ & $\begin{array}{l}\text { koko otos } \\
(\mathbf{n}=\mathbf{3 8 9 6})\end{array}$ \\
\hline lyhyt matematiikka & $10,0 \%$ & $16,6 \%$ & $24,8 \%$ & $20,0 \%$ \\
pitkä matematiikka & $65,8 \%$ & $54,0 \%$ & $12,3 \%$ & $18,0 \%$ \\
ei tietoa tai ei kirjoita & $24,3 \%$ & $29,4 \%$ & $62,9 \%$ & $62,1 \%$ \\
\hline
\end{tabular}

DTA-analyysin avulla etsittiin tekijöitä, jotka selittävät, hakeutuuko yhdeksännen vuosiluokan hyviin tai parhaisiin osaajiin kuuluva oppilas toisella asteella ammatilliseen koulutukseen vai lukioon. Erottelevia tekijöitä etsittiin ensin osaalueittain käsitteellisen muuttujamallin osioiden (ks. kuvio 1) mukaisesti ja koottiin sitten osamalleista löytyneistä tekijöistä kokonaismalli.

Koulutusvalintaa erottelevia muuttujia löytyi kaikista osa-alueista. Yksilöllisistä osaamiseen liittyvistä tekijöistä toisen asteen koulutusvalintaa selitti parhaiten äidinkielen arvosana 9. vuosiluokalla. Lukioon hakeutuneista oppilaista 64,2 prosenttia oli saanut äidinkielen arvosanaksi 9 tai 10 ja ammatilliseen koulutukseen hakeutuneista oppilaista 76,5 prosenttia sai arvosanaksi 6, 7 tai 8 .

DTA-analyysi löysi vain yhden asenteisiin liittyvän muuttujan, joka erotteli toisen asteen koulutusvalintaa. Oppilaan arvio 3. luokalla siitä, onko matematiikka yksi oppilaan lempiaineista, erotteli parhaiten toisen asteen koulutuksen valintaa $\left(\chi^{2}(1)=\right.$ 7,750; $p=0,038)$. Erottelu ei kuitenkaan ole kovin selkeä, vaikkakin lukioon hakeutuneiden osuus on 56,7 prosenttiyksikköä pienempi, jos oppilaan arvio väitteelle on ollut o-1 (asteikolla $0-4$ ) kuin jos arvio väitteelle on ollut yli 1. Toisaalta ammatillisen koulutuksen suhteen tällä ei ole juurikaan merkitystä.

Kotitaustaan liittyvistä muuttujista vanhempien lukiokoulutus erotteli parhaiten, hakeutuuko oppilas ammatilliseen koulutukseen vai lukioon $\left(\chi^{2}(1)=24,104 ; p<\right.$ o,001). Malli jakoi tiedon vanhempien suorittamasta ylioppilastutkinnosta kahteen ryhmään: 1) molemmat ylioppilaita ja 2) kumpikaan ei ylioppilas tai toinen ylioppilas. Lukioon hakeutuneista oppilaista 47,5 prosentilla molemmat vanhemmat olivat ylioppilaita ja vastaavasti ammatilliseen koulutukseen hakeutuneista oppilaista 16,2 prosentilla molemmat vanhemmat olivat ylioppilaita. 
Kouluun ja tarkemmin vertaisryhmään liittyvistä tekijöistä toisen asteen koulutusvalintaa selitti parhaiten koulussa viihtyminen 6. luokalla. Malli jakoi arvion kahteen ryhmään: 1) erittäin hyvin ja 2) melko hyvin, melko huonosti tai erittäin huonosti. Vain arvio erittäin hyvin erosi muista arvioista, jotka malli jakoi samaan ryhmään. Oppilaista, jotka olivat arvioineet viihtyvänsä koulussa erittäin hyvin 6 . luokalla, 96,5 prosenttia hakeutui lukioon.

Opetuksen pedagogisista ratkaisuista hakeutumista ammatilliseen koulutukseen tai lukioon erotteli parhaiten 9. luokan väittämä, jonka mukaan tunneilla sovelletaan matematiikan taitoja arkielämän tilanteisiin $\left(\chi^{2}(1)=13,606 ; p=0,007\right)$. Oppilaista suurin osa (79,5 \%) oli arvioinut, että soveltamista on joskus, harvoin tai ei lainkaan. Malli jakoi nämä arviot samaan ryhmään. Opetuksen pedagogisten ratkaisujen erottelukyky toisen asteen koulutusvalinnan suhteen oli heikko.

Kokonaismallia etsivään analyysiin otettiin mukaan osamalleissa esille tulleet erottelevat tekijät. Kokonaismallissa (kuvio 3) toisen asteen koulutusvalintaa erotteli parhaiten äidinkielen arvosana 9. luokalla $\left(\chi^{2}(2)=50,932 ; p<0,001\right)$. Lukioon hakeutumista indikoi erityisesti se, että opiskelija oli saanut äidinkielestä arvosanan 9 tai 10. Näiden oppilaiden valintaa ammatillisen koulutuksen ja lukion välillä erotteli seuraavaksi se, kuinka hyvin oppilas menestyi algebran osaamista mittaavissa tehtäväosioissa 9. luokan kokeessa $\left(\chi^{2}(1)=8,141 ; p=0,030\right)$. Oppilaiden, jotka saivat äidinkielen arvosanaksi 8 , koulutusvalintaa erotteli vanhempien lukiokoulutus $\left(\chi^{2}(1)\right.$ $=9,424 ; p=0,015)$. 


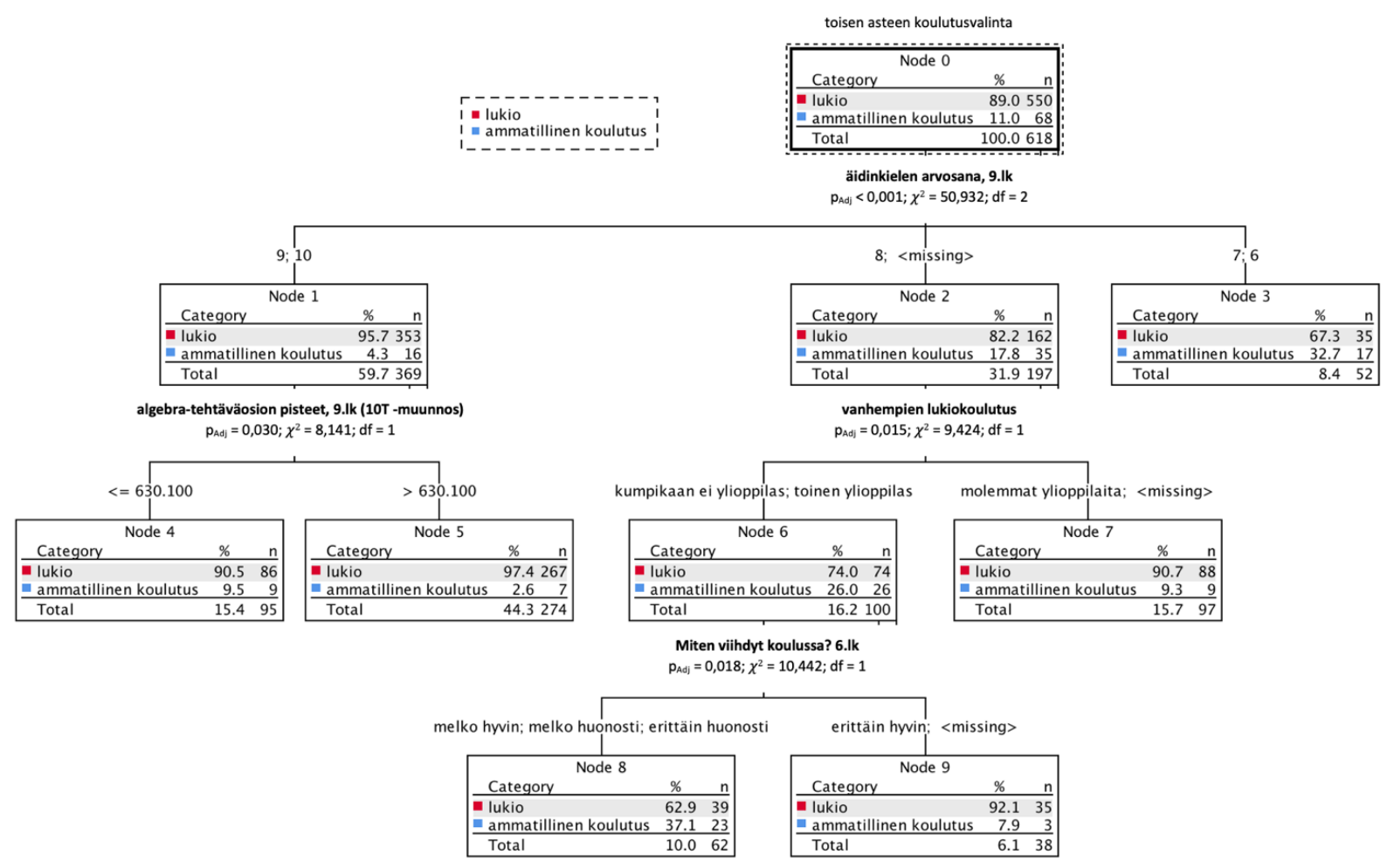

Kuvio 3. Toisen asteen koulutusvalintaa selittävien tekijöiden kokonaismalli DTA-analyysilla

\subsection{Yhdeksännen vuosiluokan matematiikan parhaiden osaajien matematiikan osaaminen toisella asteella}

Taulukkoon 6 on koottu tiedot siitä, miten 9. vuosiluokan kokeessa parhaiten menestyneiden oppilaiden matematiikan osaaminen on muuttunut toisen asteen opintojen aikana, kun osaamista on arvioitu uudelleen toisen asteen lopussa. Nähdään, että 9. luokan keskitason osaajissa on tapahtunut eniten muutoksia. Keskitason osaajia löytyy kaikista osaajaryhmistä toisen asteen lopussa. Yhdeksännen vuosiluokan hyvät ja parhaat osaajat sijoittuvat toisen asteen lopussa keskitason, hyvien ja parhaiden osaajien ryhmiin.

Taulukko 6. Osaamisen muutos eri osaajaryhmissä

\begin{tabular}{llllll}
\hline \multicolumn{1}{c}{ 12.lk } & alle keskitason & keskitaso & hyvät & parhaat & yhteensä \\
\hline keskitaso & 183 & & & & \\
hyvät & 0 & 2275 & 145 & 55 & 2658 \\
parhaat & 0 & 115 & 126 & 85 & 326 \\
yhteensä & 183 & 44 & 78 & 170 & 292 \\
\hline
\end{tabular}


Kun katsotaan tarkemmin 9. luokan parhaita osaajia ( $\mathrm{n}=292)$, heidän osaamisessaan tapahtuneista muutoksista saadaan muodostettua kolme profiilia, joita merkitään arvoin $0,-1$ ja -2 kuvaamaan osaamistason muutosta. Ensimmäisen profiilin (o) mukaisessa osaamisessa ei ole tapahtunut muutosta, vaan 9. luokan parhaat osaajat ovat parhaita osaajia myös toisen asteen lopussa $(58,2 \%)$. Toisen profiilin (-1) mukainen osaaminen on laskenut niin, että 9. luokan parhaat osaajat ovat toisen asteen lopussa hyviä osaajia (26,7 \%). Kolmannen profiilin (-2) mukainen osaaminen on laskenut eniten niin, että 9. luokan parhaat osaajat ovat keskitason osaajia toisen asteen lopussa (15,1\%).

Kuviossa 4 näkyy, miten parhaiden osaajien osaamisen muutos jakautuu kolmeen suuntaan toisen asteen opintojen aikana.

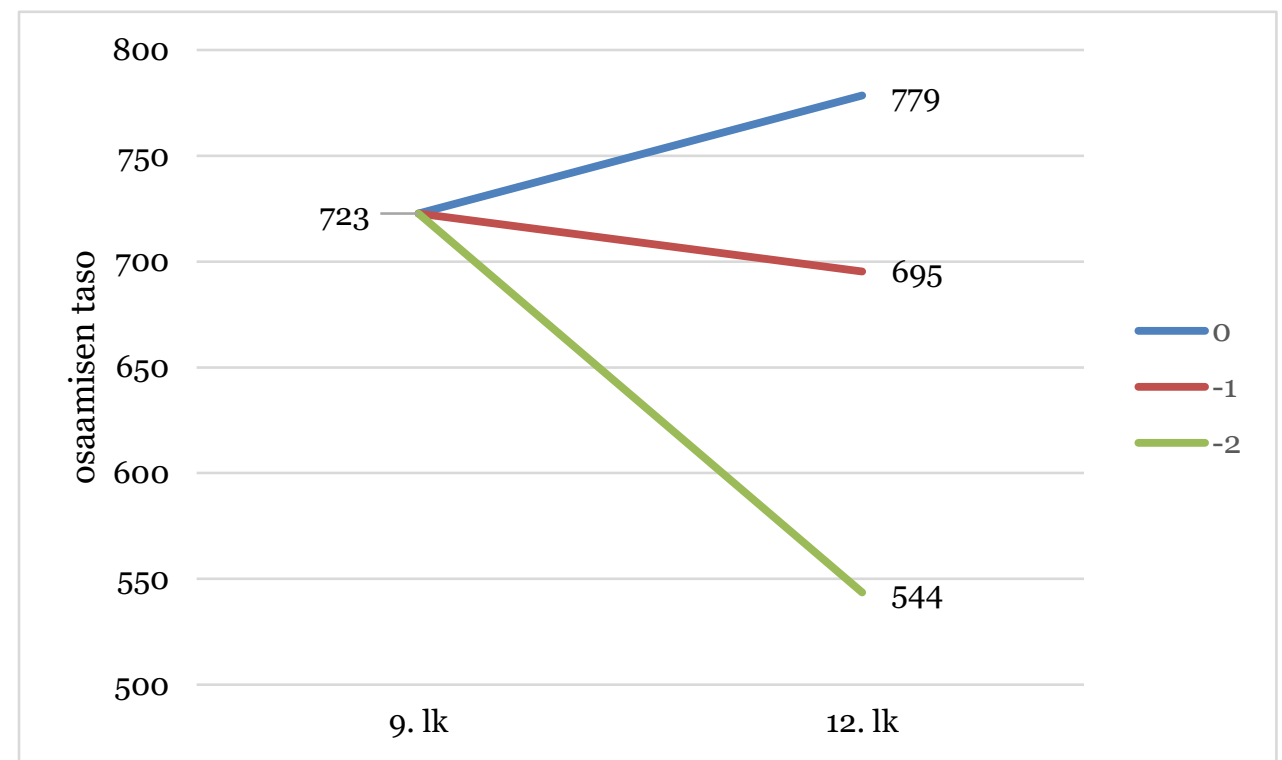

Kuvio 4. Parhaiden osaajien muutosprofiilit osaamisessa yhdeksännen luokan lopusta toisen asteen loppuun

Seuraavaksi on tarkoitus selvittää, mitkä tekijät selittävät muutoksen suuntaa. Etsitään selittäviä muuttujia ensin osa-alueittain, jotka on esitetty kuviossa 1 . Asenteista mukana ovat vain perusopetusta koskevat muuttujat. Osamallien perusteella selittävistä muuttujista kootaan lopuksi kokonaismalli.

DTA-analyysien avulla osaamisen muutosta erottelevia muuttujia löytyi yksilöllisistä tekijöistä ja kouluun liittyvistä tekijöistä opetuksen pedagogisten ratkaisujen osalta (ks. kuvio 5). Oppilaan osaamista ja valintoja koskeviin malleihin luotiin ensin jako ammatilliseen koulutukseen ja lukioon, jotta erottelevat tekijät saatiin paremmin näkyviin, koska monet toisen asteen muuttujat liittyvät suoraan 
joko ammatilliseen koulutukseen tai lukioon. Kokonaismallissa ammatillisen koulutuksen opiskelijat sijoittuivat korkeintaan 8 kurssia suorittaneiden opiskelijoiden joukkoon.

Osamalleissa selittäviksi muuttujiksi jäivät seuraavat muuttujat, jotka otettiin mukaan kokonaismallia etsivään analyysiin: matematiikan kurssimäärä lukiossa, 9. luokan koeosaaminen, käsitys omasta osaamisesta 9. luokalla, matematiikan hyödyllisyyden kokeminen 9. luokalla sekä opiskelijan arvioi siitä, että opiskeltavat asiat tulevat selväksi, päässälaskujen harjoittelu ja oman taitotason mukaiset tehtävät toisella asteella.

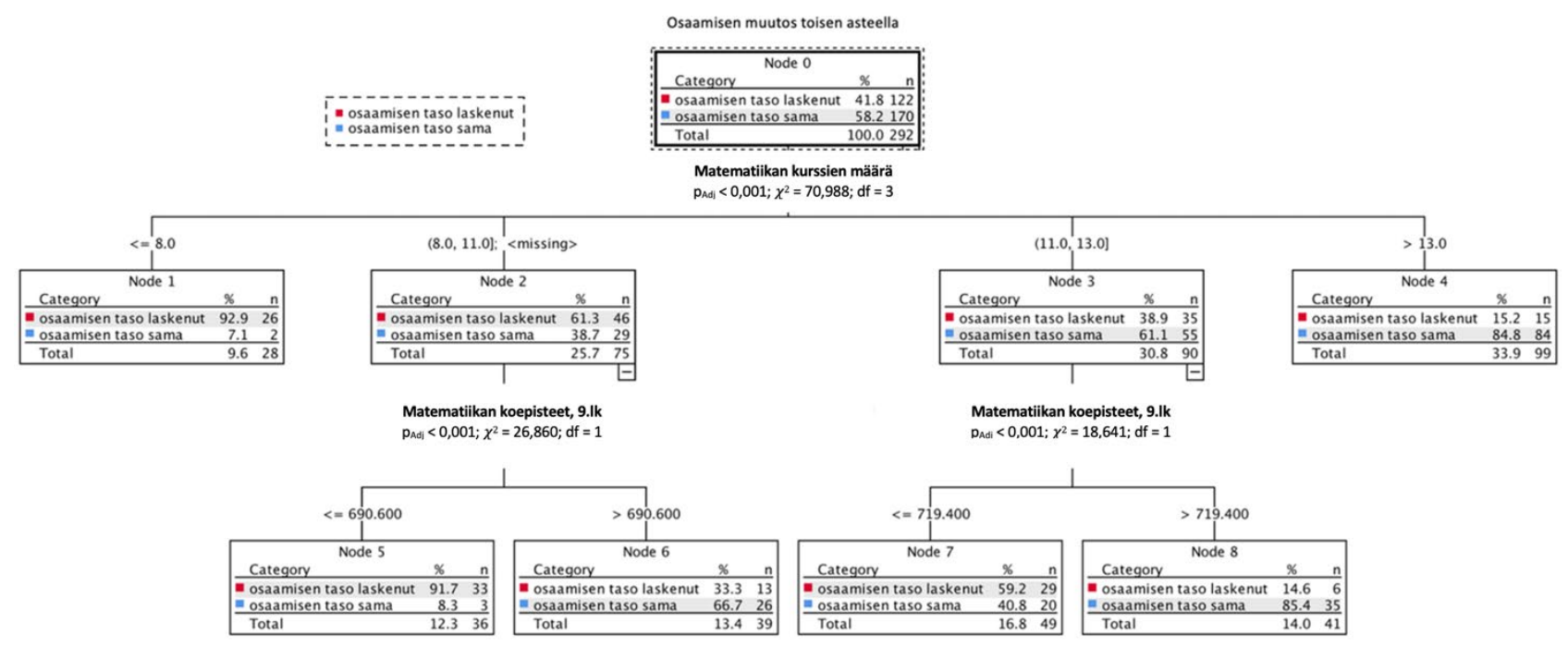

Kuvio 5. Osaamisen muutosta selittävien tekijöiden kokonaismalli DTA-analyysilla (ammatillisen koulutuksen opiskelijoiden kurssimäärä $<=8$ kurssia)

Kokonaismallissa osaamisen muutosta erotteli parhaiten matematiikan kurssimäärä lukiossa $\left(\chi^{2}(3)=70,389 ; p<0,001\right)$. Malli jakoi kurssimäärät neljään ryhmään: korkeintaan 8 kurssia, 9-11 kurssia, 12-13 kurssia tai yli 13 kurssia. Tulosten mukaan raja osaamisen muutokseen parhaista hyviin osaajiin tapahtuu 11 kurssin kohdalla. 9. luokan parhaista osaajista, jotka olivat parhaita myös toisen asteen lopussa, 81,8 prosenttia oli opiskellut matematiikkaa 12-13 kurssia tai enemmän.

Toinen erotteleva tekijä oli 9. luokan koeosaaminen, kun oppilas oli opiskellut matematiikan kursseja 9-13. Toisin sanoen menestyminen 9. luokan kokeessa ennustaa osaamisen muutosta toisella asteella. Jos yhdeksännen vuosiluokan parhaisiin osaajiin kuuluva oppilas oli saanut 9. luokan kokeesta keskimäärin alle 700 
pistettä, hänen osaamisensa taso todennäköisesti laski toisen asteen opintojen aikana.

Lineaarisen regressioanalyysin osamallien tulokset on koottu taulukkoon 7 . Vertaisryhmään liittyvistä tekijöistä ei löytynyt selittävää mallia. Askeltavan menetelmän avulla malleihin on jäänyt vain tilastollisesti merkitsevät muuttujat.

Taulukko 7. Osaamisen vaihtelua toisella asteella selittävien osamallien tulokset.

\begin{tabular}{|c|c|c|c|c|}
\hline & \multicolumn{4}{|c|}{$\begin{array}{l}\text { Parhaiden osaajien osaamisen vaihtelu toisella } \\
\text { asteella }\end{array}$} \\
\hline & $B$ & SE & beta & $p$ \\
\hline \multicolumn{5}{|l|}{$\begin{array}{l}\text { Malli 1-Yksilöön liittyvät tekijät: } \\
\text { osaaminen ja koulutusvalinnat }\end{array}$} \\
\hline Vakio & 176,584 & 68,610 & & 0,011 \\
\hline Matematiikan kurssien määrä & 9,001 & 1,785 & 0,358 & $<0,001$ \\
\hline Matematiikan arvosana 9. Ik & 27,146 & 6,644 & 0,228 & $<0,001$ \\
\hline Kokonaisosaaminen 9.lk & 0,220 & 0,074 & 0,170 & 0,003 \\
\hline Geometria -osa-alueen osaaminen 6.lk & 26,522 & 9,027 & 0,160 & 0,004 \\
\hline Matematiikan yo-kokeen laajuus & 16,576 & 7,093 & 0,166 & 0,020 \\
\hline \multicolumn{5}{|l|}{$\begin{array}{l}\text { Malli } 2 \text { - Yksilöön liittyvät tekijät: } \\
\text { asenteet }\end{array}$} \\
\hline Vakio & 619,390 & 32,073 & & $<0,001$ \\
\hline Käsitys omasta osaamisesta, 9. Ik & 16,919 & 8,076 & 0,138 & 0,037 \\
\hline $\begin{array}{l}\text { "Matematiikka on yksi } \\
\text { lempiaineistani.", 3.lk }\end{array}$ & 25,459 & 6,443 & 0,403 & $<0,001$ \\
\hline "Pidän matematiikan tunneista.", 3.Ik & $-21,178$ & 7,313 & $-0,289$ & 0,004 \\
\hline $\begin{array}{l}\text { Matematiikan hyödyllisyyden } \\
\text { kokeminen, 9.lk }\end{array}$ & 15,707 & 6,659 & 0,151 & 0,019 \\
\hline $\begin{array}{l}\text { Malli } 3 \text { - Yksilöön liittyvät tekijät - } \\
\text { sukupuoli }\end{array}$ & $-23,533$ & 8,382 & $-0,163$ & 0,005 \\
\hline Vakio & 773,506 & 12,085 & & $<0,001$ \\
\hline \multicolumn{5}{|l|}{ Malli 4-Kotitaustaan liittyvät tekijät } \\
\hline Vakio & 662,331 & 29,082 & & $<0,001$ \\
\hline $\begin{array}{l}\text { Kotonani arvostetaan koulutusta, } \\
\text { toinen aste }\end{array}$ & 19,378 & 6,588 & 0,214 & 0,004 \\
\hline \multicolumn{5}{|l|}{$\begin{array}{l}\text { Malli } 5 \text { - Kouluun liittyvät tekijät: } \\
\text { opetuksen pedagogiset ratkaisut }\end{array}$} \\
\hline Vakio & 616,652 & 26,925 & & $<0,001$ \\
\hline $\begin{array}{l}\text { Matematiikan tunneilla opiskeltavat } \\
\text { asiat tulevat selväksi (toinen aste) }\end{array}$ & 28,309 & 6,604 & 0,309 & $<0,001$ \\
\hline $\begin{array}{l}\text { Matematiikan tunneilla tehdään } \\
\text { projektitöitä (toinen aste) }\end{array}$ & $-20,658$ & 7,692 & $-0,194$ & 0,008 \\
\hline
\end{tabular}

Taulukossa 7 on esitetty osamallien tilastollisia tunnuslukuja ja kuviossa 6 näkyy näiden osamallien selitysosuudet osaamisen muutoksen vaihteluun toisella asteella. 


YKSILÖÖN LIITTYVÄT
TEKIJÄT: Osaaminen ja
koulutusvalinnat
- matematiikan kurssien
määrä lukiossa
- matematiikan arvosana, 9.lk
- koeosaaminen, 9.lk
- geometrian osaaminen 6.lk:n
kokeessa
- matematiikan yo-kokeen
laajuus

YKSILÖÖN LIITTYVÄT TEKIJÄT: Osaaminen ja koulutusvalinnat

- matematiikan kurssien määrä lukiossa

- matematiikan arvosana, 9.lk

- koeosaaminen, 9.lk

- geometrian osaaminen 6.lk:n

kokeessa

laajuus

\section{YKSILÖÖN LIITTYVÄT}

TEKIJÄT: Asenteet

- käsitys omasta

osaamisesta, 9.lk

- "Matematiikka on yksi

lempiaineistani.", 3.lk

- "Pidän matematiikan

tunneista.", 3.lk

- matematiikan hyödyllisyyden

kokeminen, 9.lk

\section{KOULUUN LIITTYVÄT} TEKIJÄT:

Opetuksen pedagogiset ratkaisut

- opiskeltavat asiat tulevat tunneilla selväksi - tunneilla tehdään projektitöitä (neg.)

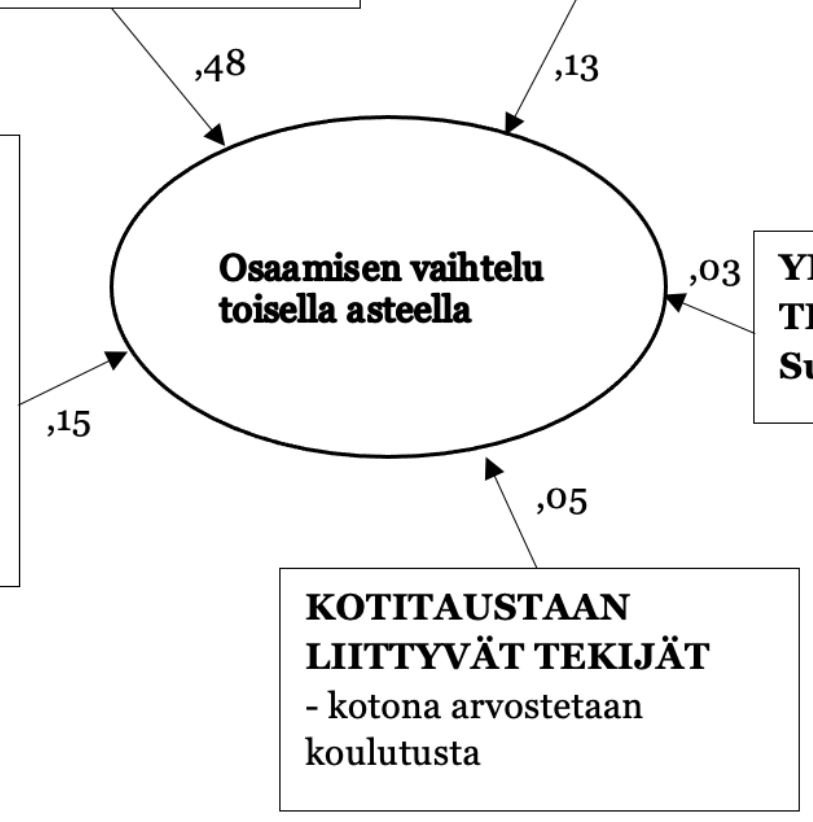

Kuvio 6. Osaamisen vaihtelua toisella asteella selittävät osamallit ja niiden selitysosuudet

Kuviosta nähdään, että osaamiseen ja koulutusvalintoihin liittyvän osamallin selitysosuus on malleista korkein $\left(R=0,700 ; R^{2}\right.$ ddj $=0,477 ; F(5,193)=37.073 ; p<$ o,001). Tulosten mukaan osaamisen muutosta selitti ensisijaisesti matematiikan kurssien määrä. Myös 9. luokan matematiikan arvosana sekä kokonaisosaaminen kansallisessa kokeessa selittivät, miten parhaiden osaajien osaaminen vaihteli toisen asteen lopussa.

Toiseksi eniten osaamisen vaihtelua selitti opetuksen pedagogiset ratkaisut $(R=$ 0,$\left.395 ; R^{2}{ }_{A d j}=0,146 ; F(2,168)=15,517 ; p<0,001\right)$. Malliin jääneet muuttujat koskevat toisen asteen opetusta. Tulosten mukaan osaaminen pysyi vakaampana toisella asteella, jos opiskeltavat asiat tulivat selväksi. Projektitöiden tekeminen näytti heikentävän osaamista toisella asteella.

Kolmanneksi eniten osaamisen vaihtelua selittivät asenteet $\left(R=0,379 ; R^{2} A d j=\right.$ $0,129 ; F(4,231)=9,668 ; p<0,001)$. Asenteista ensisijaisena selittäjänä oli oppilaan 
käsitys omasta osaamisesta yhdeksännellä vuosiluokalla. Osaamisen muutosta selittivät tulosten mukaan myös 3. luokan kaksi asenneväittämää. Jos oppilas oli pitänyt matematiikkaa yhtenä lempiaineistaan 3. luokalla, pysyi osaaminen vakaampana toisella asteella. Toisaalta matematiikan tunneista pitäminen sai mallissa negatiivisen arvon, mikä tarkoittaa, että oppilas ei ollut pitänyt matematiikan tunneista 3. luokalla. Näiden kahden asenneväittämän voidaan nähdä arvioivan kahta eri asiaa. Oppilas pitää matematiikkaa todennäköisesti yhtenä lempiaineenaan, kun kokee menestyvänsä siinä, mutta matematiikan tunnit eivät kuitenkaan välttämättä ole oppilaalle mieluisia. Lisäksi osaamisen muutosta toisella asteella selitti se, miten hyödylliseksi oppilas koki matematiikan 9. luokalla.

Kotitaustaan liittyvät tekijät ja oppilaan sukupuoli selittivät osaamisen vaihtelua vähiten. Kotitaustan osalta osaamisen muutosta selitti parhaiten se, kuinka paljon oppilaan kotona arvostetaan koulutusta $\left(R=0,214 ; R^{2}=0,046 ; F(1,180)=8,653 ; p\right.$ $=0,004)$. Sukupuolen selitysosuus osaamisen vaihtelusta oli vain 0,2 prosenttia $(R=$ 0,$\left.163 ; R^{2}=0,026 ; F(1,290)=7,883 ; p=0,005\right)$. Tulosten mukaan parhaisiin osaajiin kuuluvien poikien osaaminen pysyi tyttöjä paremmin saman tasoisena myös toisella asteella.

Osamallien perusteella laadittiin vielä kokonaismalli, joka selitti parhaiden osaajien osaamisen vaihtelusta toisella asteella 41,3 prosenttia $\left(R=0,660 ; R^{2}=\right.$ 0,$\left.436 ; R^{2}{ }_{A d j}=0,413 ; F(6,147)=18,908 ; p<0,001\right)$. Malliin vaikutti kuusi muuttujaa tilastollisesti merkitsevästi. Tulokset näkyvät taulukossa 8. Tulosten mukaan osaamisen vaihteluun vaikutti ensisijaisesti, kirjoittiko oppilas matematiikan pitkän oppimäärän ylioppilaskokeen. Tämän selitysosuutta osaamisen vaihtelusta vahvisti matematiikan kokonaisosaaminen 9. luokan kokeessa. Opetuksen pedagogista ratkaisuista malliin vaikutti, miten hyvin opiskelija koki toisella asteella, että opiskeltavat asiat tulevat oppitunneilla selväksi. Sillä, että kotona arvostetaan koulutusta, näytti olevan myös keskeinen merkitys sille, miten parhaiden osaajien osaaminen muuttui toisen asteen opintojen aikana. Malliin vaikutti 6. luokan kokeen osalta menestyminen geometria-tehtäväosiossa. Mallissa viimeisenä selittävänä muuttujana oli matematiikan kurssien määrä toisella asteella. 
Taulukko 8. Osaamisen vaihtelua toisella asteella selittävän kokonaismallin tulokset

\begin{tabular}{lllll}
\hline & \multicolumn{4}{l}{ Parhaiden osaajien osaamisen vaihtelu toisella asteella } \\
\cline { 2 - 5 } & $B$ & SE & beta & $p$ \\
\hline Kokonaismalli & & & & \\
\hline Vakio & 258,606 & 68,437 & & $<0,001$ \\
Matematiikan yo-kokeen laajuus & 25,024 & 9,095 & 0,233 & 0,007 \\
Kokonaisosaaminen, 9.Ik & 0,280 & 0,084 & 0,221 & 0,001 \\
$\begin{array}{l}\text { Opiskeltavat asiat tulevat tunneilla } \\
\text { selväksi, toinen aste }\end{array}$ & 20,033 & 5,556 & 0,230 & $<0,001$ \\
Kotonani arvostetaan koulutusta. & 17,009 & 5,388 & 0,197 & 0,002 \\
Geometrian osaaminen, 6. Ik & 29,226 & 11,872 & 0,160 & 0,015 \\
Matematiikan kurssien määrä, toinen & 6,189 & 2,601 & 0,202 & 0,019 \\
aste & & & & \\
\hline
\end{tabular}

\section{Pohdinta}

Tutkimuksessa selvitettiin ensin, mitkä tekijät selittävät yhdeksännen vuosiluokan matematiikan parhaiden osaajien hakeutumista ammatilliseen koulutukseen ja lukioon. Ensisijaisesti valintaa erotteli äidinkielen arvosana 9. luokalla. Oppilaista, jotka saivat äidinkielestä arvosanan 9 tai 10, hakeutui lähes kolminkertainen määrä lukioon verrattuna niihin, jotka saivat arvosanaksi 8. Äidinkielen osaaminen on merkityksellistä lukiossa. Äidinkielessä hyvin menestyvillä oppilailla on enemmän valmiuksia ja motivaatiota opiskella lukio-opinnoissa vaadittavia laajempia kokonaisuuksia. Niillä, jotka saivat äidinkielen arvosanaksi 8, valintaan vaikutti se, olivatko molemmat vanhemmat ylioppilaita. Koulutuksen voidaan nähdä periytyvän, kun akateemisten vanhempien lapset valitsevat todennäköisemmin akateemisen uran (mm. Myrskylä, 2009; Suominen, 2013).

Toiseksi tutkimuksessa selvitettiin, miten yhdeksännen vuosiluokan parhaiden osaajien matematiikan osaaminen muuttuu toisen asteen koulutuksen aikana ja erityisesti, mitkä tekijät selittävät muutosta, jossa osa yhdeksännen vuosiluokan parhaista osaajista ei ole parhaita osaajia enää toisen asteen päättyessä.

Yhdeksännen vuosiluokan parhaista osaajista lähes 60 prosenttia oli parhaita osaajia myös toisen asteen päättyessä, ja noin 40 prosentilla osaamisen taso laski toisen asteen hyviin osaajiin tai keskitason osaajiin. Tulosten mukaan osaamisen taso heikkenee todennäköisemmin, jos oppilas ei mene lukioon tai ei suorita lukiossa vähintään 11 matematiikan kurssia. Myös yleisellä tasolla osaamisen eroja lukioopiskelijoiden joukossa voidaan selittää matematiikan kurssimäärällä ja kurssien arvosanoilla. Metsämuurosen (2017) mukaan lyhyen matematiikan vähimmäiskurssimäärällä saadaan säilytettyä 9. luokan matematiikan osaamisen 
taso. Opiskelijoilla, jotka ovat suorittaneet yli 13 kurssia, nousee osaamisen taso selvästi, jos he ovat saaneet lukion opinnoista vähintään arvosanan 8 . Tutkimustuloksia tarkasteltaessa tulee kuitenkin ottaa huomioon, että puuttuvia havaintoja mallinnettiin osin kurssimäärän perusteella.

Osaamisen vaihtelua osaajaryhmien välillä toisen asteen lopussa selitti vahvasti kokonaisasenne matematiikkaa kohtaan toisella asteella. Tämä oli regressioanalyysin kokonaismallissa ensisijainen selittävä muuttuja yhdeksännen vuosiluokan parhaiden osaajien osaamisen vaihtelulle toisen asteen lopussa. On merkityksellistä, että asenteita matematiikkaa kohtaan ylläpidetään ja vahvistetaan toisen asteen koulutuksen aikana. Hannulan ja Tuohilammen (2017) mukaan korkea vaatimustaso ja vertaisryhmän tasaisuus saattavat alentaa lukio-opiskelijoiden asennoitumisen positiivisuutta.

Vahva matematiikan osaamisen pohja perusopetuksessa luo edellytykset sille, että oppilas menestyy matematiikassa erinomaisesti myös toisella asteella. Tulosten mukaan vahva osaaminen kokonaisuudessaan 9. luokan kansallisessa kokeessa ja geometrian vahva hallinta 6. luokan kokeessa ennustavat erinomaista osaamista myös toisella asteella. Tämä vahvistaa aikaisempia tutkimustuloksia siitä, että aikaisempi osaaminen on merkitsevä ennustaja myöhemmälle osaamiselle (mm. Niemi ym., 2020).

Opiskelijan arvio siitä, kuinka paljon kotona arvostetaan koulutusta, oli myös yksi merkitsevä tekijä yhdeksännen vuosiluokan parhaiden osaajien osaamisen kehittymiselle toisen asteen opintojen aikana. Tiedetään, että yhdeksännen vuosiluokan parhaista osaajista lähes puolella molemmat vanhemmista ovat ylioppilaita (Niemi ym. 2020), ja voidaan ajatella, että koulutuksen arvostaminen on yhteydessä koulutustasoon. Metsämuurosen (2017, s. 107) mukaan akateemiset vanhemmat saattavat herkemmin kannustaa lapsiaan parempiin suorituksiin jo varhaisina vuosina ajatellen tulevia jatko-opiskelumahdollisuuksia.

Tutkimuksessa käsiteltiin matematiikassa parhaiten menestyneitä oppilaita. Heidän osaamisensa määritettiin kansallisessa kokeessa menestymisen perusteella. Matemaattista lahjakkuutta (mm. Sternberg \& Davidson, 2005) on vaikea tunnistaa tämän tutkimuksen perusteella, mutta tutkimuksen parhaissa osaajissa voi nähdä tunnuspiirteitä matemaattisesta lupaavuudesta (Sheffield ym., 1999). Tutkimuksessa havaittiin, että keskitasoa korkeampi kyvykkyys, myönteiset asenteet matematiikkaa kohtaan ja kodin ja koulun tarjoamat mahdollisuudet luovat edellytyksiä sille, että oppilas menestyy matematiikassa erinomaisesti toisella asteella. 
Tämä tutkimus tuotti jatkokysymyksiä muun muassa siitä, miten matematiikan parhaiden osaajien kykyjä ja myönteistä suhtautumista matematiikkaa kohtaan voidaan tukea ja vahvistaa. Seuraavaksi olisi kiinnostavaa selvittää, miten matematiikan parhaiden osaajien asenteet matematiikkaa kohtaan kehittyvät.

\section{Låhteet}

Ames, C. (1992). Classrooms: Goals, structures, and student motivation. Journal of Educational Psychology, 84, 261-271. https://doi.org/10.1037/0022-0663.84.3.261

APA (2007). Report of the APA Task Force on Socioeconomic Status. Washington, DC: American Psychological Association.

Bandura A (1986). Social foundations of thought and action: A social cognitive theory. Englewood Cliff s, NJ: Prentice hall

Bandura, A., and Schunk, D.H. (1981). Cultivating competence, self-efficacy, and intrinsic interest through proximal self-motivation. Journal of Personality and Social Psychology, 41(3), 586-598. https://doi.org/10.1037/o022-3514.41.3.586

Boaler, J. (2015). Mathematical mindsets: Unleashing students' potential through creative math, inspiring messages and innovative teaching. San Francisco, CA: JosseyBass

Bradley, R. H. \& Corwyn. R. F. (2002). Socioeconomic Status and Child Development. Annual Review of Psychology, 53, 371-399.

https://doi.org/10.1146/annurev.psych.53.100901.135233

Brandl, M. \& Barthel, C. (2012). A comparative profile of high attaining and gifted students in mathematics. ICME-12 Pre-Proceedings, 1429-1438.

Bryan, R. R., Glynn, S. M. \& Kittleson, J. M. (2011). Motivation, achievement, and advanced placement intent of high school students learning science. Science Education, 95(6), 10491065. https://doi.org/10.1002/sce.20462

Chionh, Y. H., \& Fraser, B. J. (2009). Classroom environment, achievement, attitudes and selfesteem in geography and mathematics in Singapore. International Research in Geographical and Environmental Education, 18, 29-44. https://doi.org/10.1080/10382040802591530

Colangelo, N., Kerr, B., Christensen, P., and Maxey, J. (1993). A comparison of gifted underachievers and gifted high achievers. Gifted Child Quarterly, 37(4), 155-160. https://doi.org/10.1177/001698629303700404

Fennema, E. \& Sherman, J. (1976). Fennema-Sherman Mathematics Attitudes Scales: Instruments designed to measure attitudes toward the learning of mathematics. Journal for Research in Mathematics Education, 7(5), 324-326.

Gagné, F. (1995). From giftedness to talent: a developmental model and its impact on the language of the field. Roeper Review, 18(2), 103-111. https://doi.org/10.1080/02783199509553709

Gagné, F. (2000). Understanding the complex choreography of talent development through DMGT-based analysis. Teoksessa K. A. Heller, F. J. Mönks, R. J. Sternberg \& R. Subotnik (toim.) International Handbook for Research on Giftedness and Talent. Oxford: Pergamon Press, 67-79.

Hannula, M. S. \& Laakso, J. (2011). Th e structure of mathematics related beliefs, attitudes and motivation among Finnish grade 4 and grade 8 students. Teoksessa B. Ubuz (toim.), Proceedings of the 35th Conference of the International Group for the Psychology of Mathematics Education, Vol. 3. Ankara, Turkki: PME. 9-16. 
Hannula, M. S., Bofah, E., Tuohilampi, L. \& Metsämuuronen, J. (2014). A longitudinal analysis of the relationship between mathematics-related affect and achievement in Finland. Teoksessa S. Oesterle, P. Liljedahl, C. Nicol \& D. Allan (toim.), Proceedings of the Joint Meeting of $P M E 28$ and PME-NA 36, Volume 3 (ss. 249- 256). Vancouver, Canada: PME.

Hannula, M.S. \& Oksanen, S. (2013). Opettajamuuttujien yhteys osaamisen muutokseen. Teoksessa J. Metsämuuronen (toim.) Perusopetuksen matematiikan oppimistulosten pitkittäisarviointi vuosina 2005-2012. Koulutuksen seurantaraportit 2013:4. Opetushallitus. Tampere: Juvenes Print - Suomen yliopistopaino Oy, 253-294.

Härmälä M, Huhtanen M \& Puukko M (2014). Englannin kielen A-oppimäärän oppimistulokset perusopetuksen päättövaiheessa 2013. Kansallinen koulutuksen arviointikeskus. Julkaisut 2014:2. Tampere: Juvenes Print - Suomen Yliopistopaino Oy.

Harter S. (1999). The Construction of the Self. A Developmental Perspective. New York, NY: The Guildford Press.

Hautamäki J, Harjunen E, Hautamäki A, Karjalainen T, Kupiainen T, Laaksonen S, Lavonen J, Pehkonen S, Rantanen P, Scheinin P, Halinen I \& Jakku-Sihvonen R. (2008). PISAo6 Finland. Analyses, Reflections, Explanations. Ministry of Education Publications 2008:44

Hildén, R. \& Rautopuro, J. (2014). Ruotsin kielen A-oppimäärän oppimistulokset perusopetuksen päättövaiheessa 2013. Kansallinen koulutuksen arviointikeskus. Julkaisut 2014:1. Tampere: Juvenes Print - Suomen Yliopistopaino Oy.

Hiltunen, J., \& Nissinen, K. (2018). Erinomaiset matematiikan osaajat. Teoksessa J. Rautopuro, \& K. Juuti (toim.), PISA pintaa syvemmältä : PISA 2015 Suomen pääraportti. Kasvatusalan tutkimuksia, 77. Jyväskylä, Finland: Suomen kasvatustieteellinen seura, 213-234.

Hotulainen, R., Rimpelä, A., Hautamäki, J., Karvonen, S., Kinnunen, J. M., Kupiainen, S., Lindfors, P., Minkkinen, J., Pere, L., Thuneberg, H., Vainikainen, M-P. \& Wallenius, T. (2016). Osaaminen ja hyvinvointi yläkoulusta toiselle asteelle. Tutkimus metropolialueen nuorista. Tutkimuksia 398. Helsingin yliopisto. Haettu osoitteesta http://urn.fi/URN:ISBN:978-952-03-0347-1

Jiang, Y., Song, J., Lee, M. \& Bong, M. (2014). Self-efficacy and achievement goals as motivational links between perceived contexts and achievement. Educational Psychology, 34(1), 92-117. https://doi.org/10.1080/01443410.2013.863831

Johnson, W., Carothers, A., \& Deary, I. J. (2008). Sex differences in variability in general intelligence: A new look at the old question. Perspectives on Psychological Science, 3(6), 518-531. https://doi.org/10.1111/j.1745-6924.2008.00096.x

Kalalahti, M., Zacheus, T., Laaksonen, L. M., \& Jahnukainen, M. (2019). Toiselle asteelle ja eteenpäin: Eriytyvät toisen asteen koulutuspolut. Teoksessa M. Jahnukainen, M. Kalalahti, \& J. Kivirauma (toim.), Oma paikka haussa: Maahanmuuttotaustaiset nuoret ja koulutus. Gaudeamus, 71-89.

Kansanen, P. (2003). Teacher Education in Finland: Current Models and New Developments. Teoksessa B. Moon, L. Vlasceanu \& L. C. Barrows (toim.) Institutional Approaches to Teacher Education within Higher Education in Europe: Current Models and New Development. UNESCO Studies on Higher Education, 85-108.

Kass. G. (1980). An exploratory technique for investigating large quantities of categorical data. Applied Statistics, 29(2), 119-127.

Krutetskii, V. A. (1976). The psychology of mathematical abilities in schoolchildren. Chicago: University of Chicago Press.

Kupari, P. \& Nissinen, K. (2015). Matematiikan osaamisen taustatekijät. Teoksessa J. Välijärvi \& P. Kupari (toim.), Millä eväillä osaaminen uuteen nousuun? PISA 2012 tutkimustuloksia. Opetus- ja kulttuuriministeirön julkaisuja 2015: 6, 10-27. Haettu osoitteesta http://julkaisut.valtioneuvosto.fi/bitstream/handle/10024/75126/okm6.pdf 
Kuukka, K. \& Metsämuuronen, J. (2016). Perusopetuksen päättövaiheen suomi toisena kielenä (S2) -oppimäärän oppimistulosten arviointi 2015. Julkaisut 2016:13. Kansallinen koulutuksen arviointikeskus. Haettu osoitteesta https://karvi.fi/app/uploads/2016/o5/KARVI_1316.pdf.

Laine, S. (2016). Finnish elementary school teachers' perspectives on gifted education. University of Helsinki. Department of Teacher Education, Research Report 399. Haettu osoitteesta https://helda.helsinki.fi/bitstream/handle/10138/168133/Finnishe.pdf?sequence=1\&isAllo wed $=\mathrm{y}$

Leder, G. C. (2006). Affect and mathematics learning. Teoksessa J. Maasz \& W. Schloeglmann (toim.), New mathematics education and practice. The Netherlands: Sense Publishers. 203-208.

Leikin, R. (2014). Giftedness and high ability in mathematics. Teoksessa S. Lerman (toim.), Encyclopedia of mathematics education. Dordrecht: Springer Reference, 247-251. https://doi.org/10.1007/978-94-007-4978-8_65

Leino, K., Ahonen, A. K., Heinonen, N., Hiltunen, J., Lintuvuori, M., Lähteinen, S., Lämsä, J., Nissinen, K., Nissinen, V., Puhakka, E., Pulkkinen, J., Rautopuro, J., Sirén, M., Vainikainen, M-P \& Vettenranta, J. (2019). Pisa 2018 ensituloksia. Opetus- ja kulttuuriministeriön julkaisuja 2019:40. Opetus- ja kulttuuriministeriö. Haettu osoitteesta https://julkaisut.valtioneuvosto.fi/bitstream/handle/10024/161922/Pisa18ensituloksia.pdf

Lord, F. M. \& Novick M. R. (1968). Statistical theories of Mental test Scores. Addison-Wesley, Menlo Park.

Lubinski, D., and Benbow, C.P. (2006). Study of mathematically precocious youth after 35 years: uncovering antecedents for the development of math-science expertise. Perspectives on Psychological Science 1(4), 316-345. https://doi.org/10.1111/j.1745-6916.2006.00019.x

Lüftenegger, M., Kollmayer, M., Bergsmann, E., Jöstl, G., Spiel, C. \& Schober, B. (2015): Mathematically gifted students and high achievement: the role of motivation and classroom structure, High Ability Studies, 26(2), 227-243. https://doi.org/10.1080/13598139.2015.1095075

Ma, X. \& Kishor, N. (1997). Assessing the relationship between attitude toward mathematics and achievement in mathematics: A meta-analysis. Journal for Research in Mathematics Education, 28(1), 26-47. https://doi.org/10.2307/749662

Machin, S. \& Pekkarinen, T. (2008). Global sex differences in test score variability. Science, 322(5906), 1331-1332. https://doi.org/10.1126/science.1162573

Mattila, L. \& Rautopuro, J. (2013). Koulukohtaisia tuloksia. Teoksessa J. Rautopuro (toim.), Hyödyllinen pakkolasku. Matematïkan oppimistulokset perusopetuksen päättövaiheessa 2012. Koulutuksen seurantaraportit 2013:3. Opetushallitus. Helsinki: Juvenes Print Suomen Yliopistopaino Oy, 55-64.

McCoach, D. B., and Siegle, D. (2003). Factors that differentiate underachieving gifted students from high-achieving gifted students. Gifted Child Quarterly, 47(2), 144-154. https://doi.org/10.1177/001698620304700205

Metsämuuronen, J., Svedlin, R, \& Ilic, J. (2012). Change in Pupils' and Students' Attitudes toward School as a Function of Age - A Finnish Perspective. Journal of Educational and developmental Psychology, 2(2), 134-151. https://doi.org/10.5539/jedp.v2n2p134

Metsämuuronen, J. (2003). Tutkimuksen tekemisen perusteet ihmistieteissä. Jyväskylä: International Methelp Ky.

Metsämuuronen, J. (2006). Äidinkieli ja kirjallisuus -oppiaineen oppimistulosten ja asenteiden muuttuminen perusopetuksen ylempien luokkien aikana. Oppimistulosten arviointi 3/2006. Opetushallitus. Helsinki: Yliopistopaino 
Metsämuuronen, J. (2009). Metodit arvioinnin apuna. Perusopetuksen oppimistulos- arviointien ja-seurantojen menetelmäratkaisut Opetushallituksessa. Oppimis- tulosten arviointi 1/2009. Helsinki: Opetushallitus.

Metsämuuronen, J. (2010). Osaamisen ja asenteiden muutos perusopetuksen 3.-5. luokilla. Teoksessa E. K. Niemi \& J. Metsämuuronen (toim.), Miten matematiikan taidot kehittyvät? Matematiikan oppimistulokset peruskoulun viidennen vuosiluokan jälkeen vuonna 2008. Koulutuksen seurantaraportti 2010:2. Opetushallitus. Helsinki: Edita Prima Oy, 93-136.

Metsämuuronen, J. (2013). Pitkittäisaineistoon liittyviä menetelmäratkaisuja. Teoksessa J. Metsämuuronen (toim.), Perusopetuksen matematiikan oppimistulosten pitkittäisarviointi vuosina 2005-2012. Koulutuksen seurantaraportit 2013:4. Opetushallitus. Tampere: Juvenes Print - Suomen Yliopistopaino Oy. ss. 31-64.

Metsämuuronen, J. (2017). Oppia ikä kaikki - matemaattinen osaaminen toisen asteen koulutuksen lopussa 2015. Kansallinen koulutuksen arviointikeskus. Julkaisut 1:2017.

Metsämuuronen, J. \& Salonen, V. (2017). Matemaattisen osaamisen pïrteitä ammatillisen koulutuksen lopussa 2015ja pitkän ajan muutoksia. Kansallinen koulutuksen arviointikeskus. Julkaisut 2:2017. Tampere: Juvenes Print - Suomen Yliopistopaino Oy.

Metsämuuronen, J. \& Tuohilampi, J. (2017). Matemaattinen osaaminen lukiokoulutuksen lopulla 2015. Kansallinen koulutuksen arviointikeskus. Julkaisut 3:2017. Tampere: Juvenes Print Suomen Yliopistopaino Oy.

Mönks, F. J. (1992). Development of gifted children: the issue of identification and programming. Teoksessa F.J. Mönks \& W. A. M. Peters (toim.) Talent for the Future, Proceedings of the Ninth World Conference on Gifted and Talented Children. Assen: VanGorcum, 191-202.

Mönks, F. J. \& Mason, E. M. (2000). Developmental psychology and giftedness: theories and research. Teoksessa K. A. Heller, F. J. Mönks, R. J. Sternberg \& R. F. Subotnik (toim.) International Handbook of Giftedness and Talent, 2nd Edition. Oxford: Elsevier Science, 141-155. https://doi.org/10.1016/B978-008043796-5/50010-3

Murayama, K., Pekrun, R., Lichtenfeld, S. \& vom Hofe, R. (2012). Predicting Long-Term Growth in Students' Mathematics Achievement: The Unique Contributions of Motivation and Cognitive Strategies. Child Development, 84(4), 1475-1490.

https://doi.org/10.1111/cdev.12036

Myrskylä, P. (2009). Koulutus periytyy edelleen. Hyvinvointikatsaus 1/2009. Haettu osoitteesta http://www. stat.fi/artikkelit/2009/art_2009-03-16_002.html?s=0.

Niemi, H. (2011). Educating student teachers to become high quality professionals - A Finnish case. Center for Educational Policy Studies Journal, 1(1), 43-66.

Niemi, H. (2012). The societal factors contributing to education and schooling in Finland. Teoksessa H. Niemi, A. Toom, \& A. Kallioniemi (Eds.), Miracle of education. Rotterdam, Netherlands: Sense Publishers, 19-38.

Niemi, H. \& Jakku-Sihvonen, R. (2011). Teacher education in Finland. Teoksessa M. Valenčič Zuljan \& J. Vogrinc (toim.), European Dimensions of Teacher Education: Similarities and Differences. Slovenia: University of Ljubljana \& The National School of Leadership in Education, 33-51.

Niemi, L., Metsämuuronen, J., Hannula, M., \& Laine, A. (2020). Matematiikan parhaaksi osaajaksi kehittyminen perusopetuksen aikana. Ainedidaktiikka, 4(1), 2-33. https://doi.org/10.23988/ad.83384

O’Dea, R. E., Lagisz, M., Jennions, M. D., \& Nakagawa, S. (2018). Gender differences in individual variation in academic grades fail to fit expected patterns for STEM. Nature communications, 9(1), 3777. https://doi.org/10.1038/s41467-018-06292-0 
OECD. (2007). PISA 2006: Science Competencies for Tomorrow's World Executive Summary. Haettu osoitteesta http://www.oecd.org/pisa/pisaproducts/39725224.pdf

OECD. (2010). PISA 2009 Results: Executive Summary. Haettu osoitteesta https://www.oecd.org/pisa/pisaproducts/46619703.pdf

Opetushallitus. (2003). Lukion opetusuunnitelman perusteet 2003. Nuorille tarkoitetun lukiokoulutuksen opetussuunnitelman perusteet. Määräys 33/011/2003. Opetushallitus. Vammala: Vammalan kirjapaino Oy.

Opetushallitus. (2004). Perusopetuksen opetussuunnitelman perusteet 2004. Opetushallitus. Vammala: Vammalan kirjapaino Oy.

Opetushallitus. (2009). Ammatillisen perustutkinnon perusteet. Lapsi-ja perhetyön koulutusohjelma/osaamisala. Määräys 18/011/2009. Opetushallitus. Vaasa: Oy Fram Ab.

Opetushallitus. (2014). Perusopetuksen opetussuunnitelman perusteet 2014. Määräykset ja ohjeet 2014: 96. Opetushallitus. Tampere: Juvenes Print - Suomen Yliopistopaino Oy.

Ouakrim-Soivio, N. \& Kuusela, J. (2012). Historian ja yhteiskuntaoipin oppimistulokset perusopetuksen päättövaiheessa 2011. Koulutuksen seurantaraportit 2012:3. Opetushallitus. Tampere: Juvenes Print - Tampereen yliopistopaino Oy.

Ouakrim-Soivio, N. (2013). Toimivatko päättöarvioinnin kriteerit? Oppilaiden saamat arvosanat ja Opetushallituksen oppimistulosten seuranta-arviointi koulujen välisten osaamiserojen mittareina. Raportit ja selvitykset 2013: 9. Haettu osoitteesta https://helda.helsinki.fi/bitstream/handle/10138/41026/ouakrimsoivio_vaitoskirja.pdf?sequence $=1$ \&isAllowed $=\mathrm{y}$

Pajares, F. (2003). Self-efficacy beliefs, motivation, and achievement in writing: a review of the literature. Reading \& Writing Quarterly, 19(2), 139-158.

https://doi.org/10.1080/10573560308222

Pedhazur, E. (1982). Multiple Regression Analysis in Behavioral Research. New York: Holt, Rinehart and Winston.

Phillips, N., and Lindsay, G. (2006). Motivation in gifted students. High Ability Studies, 17(1), 5773. https://doi.org/10.1080/13598130600947119

Räsänen, P. \& Närhi, V. (2013). Heikkojen oppijoiden koulupolku. Teoksessa J. Metsämuuronen (toim.), Perusopetuksen matematiikan oppimistulosten pitkittäisarviointi vuosina 20052012. Koulutuksen seurantaraportit 2013:4. Opetushallitus. Tampere: Juvenes Print Suomen Yliopistopaino Oy. 173-230.

Räsänen, P., Närhi, V. \& Aunio, P. (2010). Matematiikassa heikosti suoriutuvat oppilaat perusopetuksen 6. luokan alussa. Teoksessa E. K. Niemi \& J. Metsämuuronen (toim.), Miten matematiikan taidot kehittyvät? Matematiikan oppimistulokset peruskoulun viidennen vuosiluokan jälkeen vuonna 20o8. Koulutuksen seurantaraportti 2010:2. Opetushallitus. Helsinki: Edita Prima Oy. ss. 165-204.

Rasch, G. (1960). Probabilistic models for some intelligence and attainment tests. Danmarks Pædagogishe Institut. Studies in Mathematic Psychology I. Copenhagen: Nielsen \& Lydiche.

Renzulli, J. S. \& Reis, S. M. (1985). The Schoolwide enrichment model: A comprehensive plan for educational excellence. Mansfield Center, CT: Creative Learning Press.

Renzulli, J.S. (2002). Emerging conceptions of giftedness: building a bridge to the new century. Exceptionality 1O(2), 67-75. https://doi.org/10.1207/S15327035EX1002_2

Robinson, K. \& Harris, A. (2014). The broken compass: parental involvement with children's education. USA: Harvard university press.

Ryan, R. M., and Deci, E. L. (2000). Self-determination theory and the facilitation of intrinsic motivation, social development, and well-being. American Psychologist, 55(1), 68-78. https://doi.org/10.1037/0003-066X.55.1.68 
Saarinen, A. (2020). Equality in Cognitive Learning Outcomes: the Roles of Educational Practices. Helsinki Studies in Education, number 97. Haettu osoitteesta https://helda.helsinki.fi/bitstream/handle/10138/320436/saarinen_aino_dissertation_20 20.pdf?sequence $=1 \&$ is Allowed $=\mathrm{y}$

Sahlberg, P. (2011). The Professional Educator: Lessons from Finland. American Educator, 35(2), 34-38. Haettu osoitteesta https://files.eric.ed.gov/fulltext/EJ931215.pdf

Schneider, B. (1993). Children's Social Competence in Context: The Contributions offamily, school and culture. University of Ottawa. Canada: Pergamon Press

Sheffield, L. J., Bennett, J., Berriozabal, M., DeArmond, M. \& Wertheimer, R. (1999). Report of the NCTM task force on the mathematically promising. Teoksessa L. J. Sheffield (toim.), Developing mathematically promising students. Reston, VA: NCTM, 309-316.

Singer, F. M., Sheffield, L. J., Freiman, V. \& Brandl, M. (2016). Research On and Activities For Mathematically Gifted Students, ICME-13 Topical Surveys. https://doi.org/10.1007/978-3319-39450-3_2

Sternberg, R. J. \& Davidson, J. E. (toim.) (2005). Conceptions of giftedness. New York: Cambridge University Press.

Suárez-Álvarez, J., Fernández-Alonso, R. \& Muñiz, J. (2014). Self-concept, motivation, expectations and socioeconomic level as predictors of academic performance in mathematics. Learning and Individual Differences, 30, 118-123.

https://doi.org/10.1016/j.lindif.2013.10.019

Suominen, E. (2013). Korkeakoulutus periytyy - mitä voidaan tehdä?. Tulevaisuuden yliopisto. Haettu osoitteesta http://tulevaisuudenyliopisto.fi/post/64670610356/korkeakoulutusperiytyy-mit\%C3\%A4- voidaan-tehd\%C3\%A4

Szabo, A. (2015). Mathematical problem-solving by high achieving students: Interaction of mathematical abilities and the role of the mathematical memory. Teoksessa K. Krainer \& N. Vondrová (toim.) Proceedings of CERME9. Prague: Czech Republic: Charles University and ERME, 1087-1093.

Tabachnick, B. G., \& Fidell, L. S. (2007). Using Multivariate Statistics. Fifth Edition. Boston: Pearson.

TIMSS. (2009). TIMSS 2007 U.S. Technical Report and User Guide. Haettu osoitteesta http://nces.ed.gov/pubs2009/2009012_2.pdf

Tirri, K. \& Kuusisto, E. (2013). How Finland Serves Gifted and Talented Pupils. Journal for the Education of the Gifted, 36(1), 84-96. https://doi.org/10.1177/0162353212468066

Tuohilampi, L., Hannula, M. \& Varas, L. (2013). 9-year old students' self-related belief structures regarding mathematics: a comparison between Finland and Chile. Teoksessa M. S. Hannula, P. Portaankorva-Koivisto, A. Laine \& L. Näveri (toim.), Current state of research on mathematical beliefs XVIII: Proceedings of the MAVI-18 Conference, September 12-15, 2012, Helsinki, Finland. Suomen ainedidaktisen tutkimusseuran julkaisuja: Ainedidaktisia tutkimuksia, no. 6, Suomen ainedidaktinen tutkimusseura ry, Helsinki, 15-26.

Ukkola, A. \& Metsämuuronen, J. (2019). Alkumittaus - Matematiikan ja äidinkielen ja kirjallisuuden osaaminen ensimmäisen luokan alussa. Julkaisut 17:2019. Helsinki: Kansallinen koulutuksen arviointikeskus. Haettu osoitteesta: https://karvi.fi/app/uploads/2019/o7/KARVI_1719.pdf

Välijärvi, J. (2017). PISA 2015: oppilaiden hyvinvointi. Jyväskylä: Koulutuksen tutkimuslaitos. Vettenranta, J., Välijärvi, J., Ahonen, A., Hautamäki, J., Hiltunen, J., Leino, K., Läheinen, S., Nissinen, K., Nissinen, V., Puhakka, E., Rautopuro, J. \& Vainikainen, M-P. (2016). PISA 15 Ensituloksia. Huipulla pudotuksesta huolimatta. Helsinki: Opetus- ja kulttuuriministeriön julkaisuja 2016: 41. 
Vlahovic-Stetic, V., Vidovic, V. V., and Arambasic, L. (1999). Motivational characteristics in mathematical achievement: a study of gifted high-achieving, gifted underachieving and non-gifted pupils. High Ability Studies, 10(1), 37-49. https://doi.org/10.1080/1359813990100104

Wellisch, M., and Brown, J. (2012). An integrated identification and intervention model for intellectually gifted children. Journal of Advanced Academics, 23(2), 145-167. https://doi.org/10.1177/1932202X12438877

Williams, T. \& Williams, K. (2010). Self-efficacy and performance in mathematics: Reciprocal determinism in 33 nations. Journal of Educational Psychology, 102(2), 453-466. https://doi.org/10.1037/a0017271

Winner, E. (2000). The origins and ends of giftedness. American Psychologist, 55(1), 159-169. https://doi.org/10.1037/0003-066X.55.1.159

Zimmerman, B.J. (2000). Self-efficacy: an essential motive to learn. Contemporary Educational Psychology, 25(1), 82-91. https://doi.org/10.1006/ceps.1999.1016 